Pontifícia Universidade Católica DO RIO DE JANEIRO

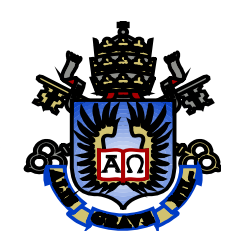

Nayara Fernandes Coelho

\title{
A experiência do exílio nas fotografias de Alice Brill
}

\author{
Dissertação de Mestrado
}

Dissertação apresentada como requisito parcial para obtenção do grau de Mestre pelo Programa de Pós-Graduação em História Social da Cultura do Departamento de História da PUC-Rio.

Orientador: Prof ${ }^{\circ}$ Maurício Barreto Alvarez Parada

Rio de Janeiro

Dezembro de 2018 


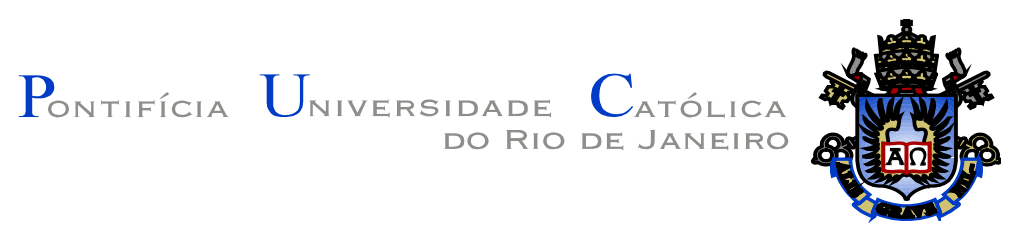

Nayara Fernandes Coelho

\section{A experiência do exílio nas fotografias de Alice Brill}

Dissertação apresentada como requisito parcial para obtenção do grau de Mestre pelo Programa de PósGraduação em História Social da Cultura do Departamento de História do Centro de Ciências Sociais da PUC-Rio. Aprovada pela Comissão Examinadora abaixo assinada.

Prof. Maurício Barreto Alvarez Parada

Orientador

Departamento de História - PUC-Rio

Prof ${ }^{a}$ Manuela Rodrigues Fantinato

Departamento de Filosofia - PUC-Rio

Prof. Joaquim Marçal Ferreira de Andrade

Departamento de Artes \& Design - PUC-Rio

Prof. Augusto César Pinheiro da Silva

Vice-Decano de Pós-Graduação do Centro de Ciências Sociais - PUC-Rio

Rio de Janeiro, 19 de dezembro de 2018 
Todos os direitos reservados. É proibida a reprodução total ou parcial do trabalho sem autorização do autor, do orientador e da universidade.

\section{Nayara Fernandes Coelho}

Graduação em História pela Pontifícia Universidade Católica do Rio de Janeiro. Foi bolsista no Programa de Educação Tutorial e bolsista de Iniciação Científica na pesquisa 'Outro retrato do Brasil: cultura e história na obra crítica de Otto Maria Carpeaux'. Trabalhou como pesquisadora no Instituto Moreira Salles, no acervo do fotógrafo José Inácio Parente e no acervo do fotógrafo e colecionador Joaquim Paiva.

Ficha Catalográfica

Coelho, Fernandes Nayara

A experiência do exílio nas fotografias de Alice Brill / Nayara Fernandes Coelho; orientador: Maurício Barreto Alvarez Parada. 2018.

$88 \mathrm{f.} ; 30 \mathrm{~cm}$

Dissertação (mestrado)-Pontifícia Universidade Católica do Rio de Janeiro, Departamento de História, 2018.

Inclui bibliografia

1. História - Teses. 2. História social da cultura. 3. Alice Brill. 4. Exílio. 5 Fotografia. I. Parada, Maurício Barreto Alvarez. II. Pontifícia Universidade Católica do Rio de Janeiro. Departamento de História. III. Título.

CDD: 900 


\section{Agradecimentos}

Gostaria de agradecer a todos que fizeram parte dessa trajetória, em especial a minha mãe, que sempre esteve ao meu lado. Ao meu querido orientador que me ajudou de inúmeras formas com essa dissertação, que trilhou comigo esse caminho árduo de graduação e pós graduação, não tenho palavras pra descrever o quão grata eu sou.

Quero agradecer também aos meus amigos, que seguraram a minha mão e me auxiliaram por este caminho, em especial a Bianca, Ana, Karla, Isadora, Ragda, Manuela, Ana Claudia, Ligia, Lilian, Gilda, Fatima, Edson, Albert, Lena, Sandra e a todos do grupo de orientação do professor Mauricio Parada.

Muito obrigada ao José Inacio Parente e ao Joaquim Paiva, por todas as conversas sobre fotografia, todo o apoio a esse trabalho e a parceria de trabalho.

Obrigada também aos meus queridos anjos do departamento de História da PUC-Rio, Claudio, Cleusa, Anair e Edna pelo apoio incondicional.

O presente trabalho foi realizado com apoio da Coordenação de Aperfeiçoamento de Pessoal de Nível Superior - Brasil (CAPES) - Código de Financiamento 001. 


\section{Resumo}

Coelho, Fernandes Nayara; Parada, Maurício Barreto Alvarez: A experiência de exílio nas fotografias de Alice Brill. Rio de Janeiro, 2018. 88p. Dissertação de Mestrado - Departamento de História, Pontifícia Universidade Católica do Rio de Janeiro.

Esta dissertação tem como propósito apresentar as fotografias de Alice Brill e sua relação com a trajetória pessoal da fotógrafa. O ponto de encontro entre as fotografias que ela produz e sua vida é o exílio, que transforma sua compreensão sobre o mundo a sua volta. Alice Brill nasceu na Alemanha em 1920 e residiu em Hamburgo até 1934, quando foi obrigada a deixar o país por causa de sua origem judaica. Neste período de exílio, ela percorreu um longo caminho até seu destino final, o Brasil. Está trajetória transformou o olhar de Brill e sua adaptação na cidade de São Paulo foi auxiliada pela sua arte. Dessa forma a artista expressou as dissonâncias que estava vivendo. Dentre sua vasta obra está a fotografia, que ela construiu ao longo da década de 50, apresentando um olhar distinto sobre as escolhas dos temas fotografados. Dentre os conjuntos que Brill construiu, as fotografias do hospital do juquery feitas em 1950 são importantes por diversos aspectos, pelo valor documental e artístico.

\section{Palavras-chave}

Alice Brill; Exílio; Fotografia 


\section{Abstract}

Coelho, Fernandes Nayara; Parada, Maurício Barreto Alvarez (Advisor). Exile experiences in Alice Brill's photographs. Rio de Janeiro, 2018. 88p. Dissertação de mestrado - Departamento de História, Pontifícia Universidade Católica do Rio de Janeiro.

The purpose of this dissertation is to present Alice Brill's photographs as well as their relationship with her personal life. The meeting point between her photographs and personal life is exile, which changes her understanding of the world. Alice Brill was born in Germany in 1920 and she has lived in Hamburg until 1934, when she was forced to leave her country due to her Jewish background. While in exile, she has traveled a long journey until her final destination, Brazil. These life experiences transformed Brill's gaze and her settlement in the city of São Paulo was facilitated by her art. In this way the artist expressed the dissonances she was experiencing. Among her vast work is photography, which she has built throughout the 1950s, presenting a distinct look to the subjects of her photography. Among the sets that Brill built, the photographs of the Juquery Hospital made in 1950 are important for several aspects, especially for their documentary and artistic value.

\section{Keywords}

Alice Brill; Exile; Photography 
Sumário

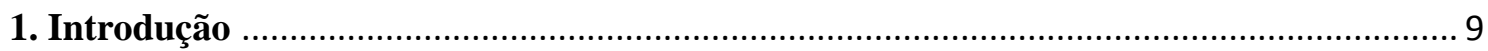

2. A experiência do exílio na trajetória da artista Alice Brill ............................................. 14

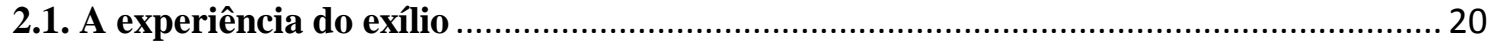

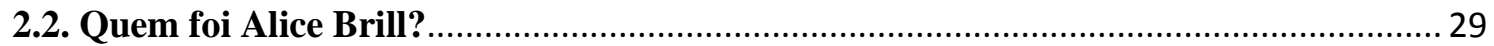

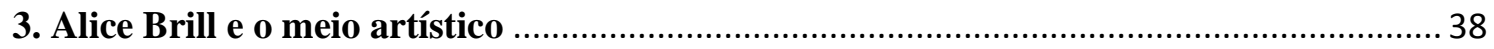

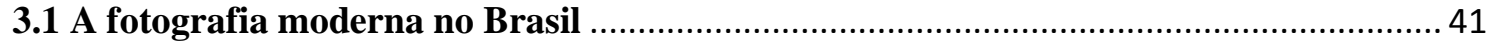

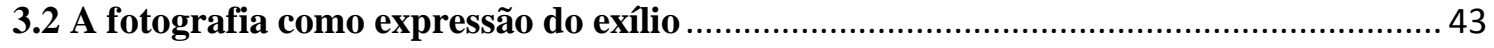

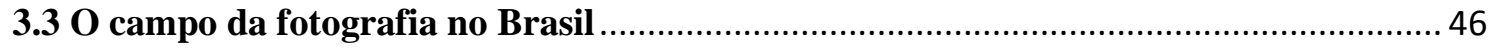

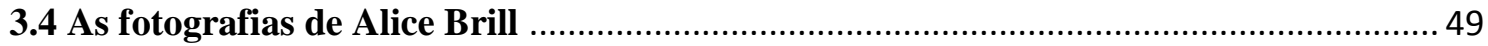

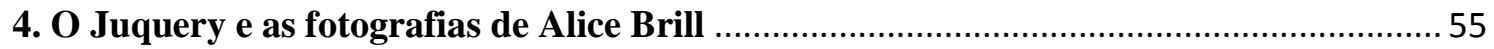

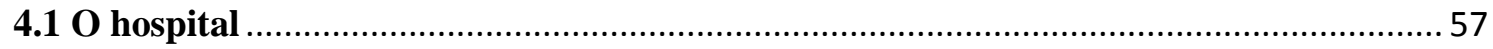

4.2 A relação entre o ateliê e as fotografias de Alice Brill.................................................. 60

4.3 As fotografias de Alice Brill no Hospital Psiquiátrico do Juquery ................................ 63

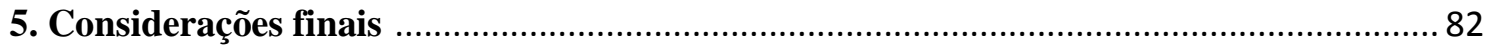

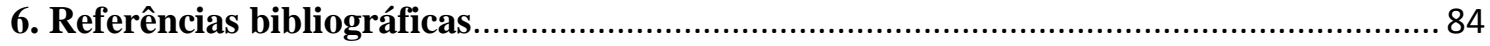


Sempre estive muito ligada à representação das imagens, praticando desenho e pintura, além da fotografia. Esta atividade me ajudou muito a superar as dificuldades que a vida de emigrante impõe.

Alice Brill, 1933. 


\section{1- Introdução}

Essa dissertação trabalha com três pontos distintos: o exílio, a fotografia e a obra fotográfica de Alice Brill. O terceiro ponto, ou seja, a produção artística primorosa de Alice Brill é a união de dois dos meus maiores interesses dentro do mundo acadêmico. Venho ao longo de oito anos trabalhando com fotografias, com isso aprendi o quanto é difícil descrever com palavras no âmbito estético. Não por falta de embasamento teórico, mas sim por acreditar que certas narrativas só devem ser feitas através de imagens.

Nesse âmbito busco nesta dissertação, o que para mim é um trabalho árduo, colocar em palavras a construção de um pensamento estético. Alice Brill tem uma relevância significativa nessa escolha, pois ela possui um trabalho que tem como base suas experiências de vida, que podem ser percebidas através das escolhas de seu trabalho artístico.

Meu interesse pelo tema surgiu, inicialmente, na minha pesquisa como bolsista de Iniciação Científica (PIBIC), orientada pelo professor Maurício Parada que acabou se transformando na minha monografia de conclusão da Graduação em História. Neste trabalho amplio meus estudos em relação a obra da Alice Brill buscando estudar e investigar a experiência de exílio da artista, uma consequência da imigração em massa que ocorreu durante as décadas de 1930 e 1940 e tendo como principal causa as políticas antissemitas do governo nazista da Alemanha. Entre os que imigraram, estavam artistas, intelectuais e literatos europeus, muitos dos quais vieram para o Brasil.

Em função da pesquisa de Iniciação Científica (PIBIC), entrei em contato com o acervo fotográfico do Instituto Moreira Salles. Lá, pesquisei o trabalho de vários fotógrafos exilados, dentre eles, está a fotógrafa Alice Brill. Esse trabalho é um esforço para mapear e compreender a trajetória do deslocamento vivido por essa artista. 
O ponto inicial dessa pesquisa é o exílio, que não pode ser compreendido apenas como a saída de um local para outro, ele ultrapassa o âmbito geográfico. $\mathrm{O}$ exílio é, neste trabalho, uma expressão de sentimentos e construções de compreensão sobre o mundo vivido que se torna único. A solidão, o estranhamento e a busca por novas compreensões sobre o mundo fazem do exilado um campo aberto de experimentos. Essas experiências eclodem na vida de Alice Brill em suas fotografias; elas foram a primeira forma que a artista obteve de se expressar, ao deixar sua pátria, a Alemanha, durante o longo percurso que trilhou até chegar ao Brasil. A câmera fotográfica foi para Alice Brill uma espécie de lugar seguro, ao mesmo tempo que auxíliou na compreensão sobre os lugares que ela esteve.

Ao chegar no Brasil esse processo se esgota, retomando apenas em 1947 quando Alice Brill foi estudar artes nos Estados Unidos. Ao voltar ao Brasil, a artista começa a construir uma carreira como fotógrafa, construindo uma obra fotográfica muito importante para a arte brasileira nos anos 50. Seu trabalho é amplo, suas escolhas sobre os temas de suas fotografias demonstram a maneira singular como seriam elaboradas essas imagens. Essa forma distinta de fotografar é o ponto onde floresce a sua bagagem de vida.

Nascida (1920/2013) em Colônia, na Alemanha e de origem judaica, Alice Brill era filha de influentes artistas, sendo a mãe jornalista e o pai artista plástico. Com a ascensão ao poder do nazismo, em 1933, sua mãe, Marte Brill, foi obrigada a deixar a Alemanha, e assim iniciou um trajeto longo de fuga que teve como destino final o Brasil, em 1934. Alice Brill se estabeleceu em São Paulo e construiu uma carreira plural no campo das artes, pois possuía trabalhos como pintora, fotógrafa e ensaísta. O período em que trabalhou com fotografia se restringe a década de 1950, que será analisada neste trabalho. A proposta do presente trabalho é analisar como a experiência de deslocamento influenciou a sua obra.

A abordagem teórica utilizada para compreender os estudos vinculados às experiências de exílio do século XX dialogam com o crítico literário Edward Said e o filosofo Vilém Flusser. Suas trajetórias foram marcadas por experiências de exílio e possuem trabalhos que discutem de forma teórica, ao mesmo tempo em que relatam 
suas próprias vivências. Os livros apresentados neste trabalho são: Bondelos ${ }^{1}$, autobiografia escrita por Vilém Flusser, publicada em 1990 na Alemanha, em que o autor narra sua história, faz reflexões sobre seu trabalho como professor e escritor, além de repensar sua trajetória de exilio. O outro livro é Fora do lugar ${ }^{2}$, escrito por Edward Said em 1998, uma obra autobiográfica que relaciona suas memórias e com as mudanças de visão sobre o mundo causadas pelo seus deslocamentos. A terceira obra utilizada como fundamentação teórica nessa dissertação foi Reflexões sobre o exílio, escrito também por Edward Said. O livro é formado por um conjunto de ensaios que discutem o exílio através de indivíduos que vivenciaram essa experiência. Portanto, esses dois autores possuem estudos que se concentram nas consequências provocadas pelos deslocamentos e que acabam por definir novas concepções de identidades e vanguardas artísticas. Essas imigrações são resultantes das políticas do século XX que provocam um intenso trânsito cultural, o que leva a gerar novas identidades.

Para analisar a obra fotográfica feita por Alice Brill, foi necessária uma pesquisa sobre os movimentos artísticos no Brasil ao longo da década de 1950. A história da fotografia será discutida através dos textos da historiadora Ana Maria Maud e da arquiteta Helouise Costa que analisam a moderna fotografia brasileira, área que surge no país a partir dos anos de 1950. Para essas autoras, o Brasil vivia um momento de grande transformação decorrente da expansão das indústrias, o crescimento das cidades e da imprensa que foram importantes para o desenvolvimento da fotografia moderna no Brasil.

O presente trabalho é dividido em três capítulos. O primeiro capítulo tem como foco a análise do movimento migratório que foi uma das consequências das políticas da segunda metade do século XX e a trajetória de vida da fotógrafa Alice Brill. Sua vida é marcada por um percurso de exílio que influencia sua obra; seu trabalho como artista a insere dentro de um novo cotidiano e uma nova cultura. Para Alice Brill a pátria não era mais um lugar plausível, assim como o novo país também era algo estranho em um primeiro momento. A sua arte se torna um lar, o seu lar, uma pátria.

\footnotetext{
${ }^{1}$ FLUSSER, Vilém. Bodenlos: uma autobiografia filosófica. São Paulo: Annablume, 2007.

${ }^{2}$ SAID, Edward. Fora do Lugar. São Paulo: Companhia das Letras, 2004.
} 
Nesse capitulo estão inseridos Edward Said e Vilém Flusser, autores que vivenciaram experiências parecidas como a de Alice Brill e relataram essas experiências através de seus escritos e suas profissões como intelectuais. Buscando identificar uma aproximação entre as três vivências, é possível inferir que são as formas de pensar identidade e seu papel como pessoas que tiveram que abandonar sua pátria e percorrer outros caminhos o que os aproxima.

O segundo capítulo se concentra nos estudos sobre a fotografia no Brasil durante a década de 1950 e como esse movimento quer construir uma nova identidade brasileira. A fotografia ganha destaque nessa década, principalmente na área de fotojornalismo. Além do informativo Novidades Fotóptica, que será transformado em revista em 1970, o Foto Cine Clube Bandeirante edita o Anuário Brasileiro de Fotografia em 1957, sendo essas publicações alguns exemplos da importância que a fotografia passa a alcançar no Brasil naquela década.

Todas essas referências sobre a fotografia na década de 1950 são importantes para entender Alice Brill como uma fotógrafa que teve um trabalho importante na área fotográfica no Brasil. Nesse sentido, este capítulo tem como intuito buscar identificar a relação entre o movimento fotográfico dos anos 50 e o trabalho de Alice Brill, construindo o espaço em que a artista se inseriu e como isso influenciou sua profissão como fotógrafa. Apresenta as principais influências relacionadas ao trabalho da artista, como o grupo Santa Helena, a revista Habitat criada por Lina e Pietro Bo Bardi e seu contato com o circulo de artistas que foram fundamentais em seu percurso como fotógrafa.

É importante ressaltar que os trabalhos que foram escritos sobre Alice Brill nos levam a perceber a escassez de informações e de publicações que abarquem a vida da artista. Apesar de existir, apenas, cinco trabalhos acadêmicos que são relacionados a vida e obra de Alice Brill, eles foram fontes importantes e marco para elaborar dessa dissertação. Nesse capitulo, apresento três desses trabalhos que ajudaram a conhecer a carreira artística de Alice Brill.

O capítulo três tem como objetivo analisar o trabalho fotográfico de Alice Brill, concentrando a análise nas fotografias realizadas pela artista no Hospital Psiquiatrico de Juquery, no ano de 1950. Para o desenvolvimento desse capítulo, 
utilizei dois trabalhos acadêmicos com intuito de analisar o material fotográfico da artista produzida no Hospital do Juquery: a tese de doutorado em História da Arte, escrita por Tatiana Gonçalves, "A representação do louco e da loucura nas imagens de quatro fotógrafos brasileiros do século XX: Alice Brill, Leonid Streliaev, Cláudio Edinger, Claudia Martins" e o artigo da historiadora Lena Shufler, "Photograpy from the Psyche: Alice Brill in the clinic of Juqueri, São Paulo 1950”. Apesar de possuírem objetivos diferentes, esses trabalhos analisam as fotografias de Alice Brill possibilitando compreender os estudos ligados as fotografias no Brasil, como também, discorrer sobre as pesquisas feitas nesse conjunto fotográfico.

Nesses trabalhos são apresentadas 16 imagens que correspondem ao conjunto do Juquery. Elas apresentam três momentos distintos: as fotografias feitas no atêlie de artes, no patio externo e, por último, as imagens das obras feitas pelos artistas/internos do Hospital Psiquiátrico. Isso possibilita uma comprensao sobre a obra da artista e também seu intuito ao formular esse conjunto.

Esse conjunto é importante pelo seu valor estético, mas também, por se tratar de um conjunto fotográfico histórico tendo em vista que Alice Brill foi a primeira fotógrafa a retratar o ateliê de artes do Hospital Psiquiátrico do Juquery. O ateliê era uma novidade como tratamento terapêutico e o conjunto fotográfico acaba por registrar esse evento, demonstrando a importância do conjunto apresentado neste capitulo.

Ao apresentar esse conjunto fotográfico pretende-se unir os assuntos tratados nos dois primeiros capítulos, pois retrata as fotografias de Alice Brill e sua forma de fotografar, como também, o tema escolhido para esse conjunto construindo um paralelo com o exílio. Nesse caso ao analisar as fotografias feitas no Hospital do Juquery fica claro que, para os artista/internos, a arte também era um local de reconstrução da identidade, ou seja, podia ser compreendida como uma pátria. Da mesma forma, a arte foi para Alice Brill a reconstrução de sua identidade e a forma que ela encontrou para se adaptar a uma nova pátria, nesse caso o Brasil. 


\section{A experiência do exílio na trajetória da artista Alice Brill}

"Ver 'o mundo inteiro como uma terra estrangeira' possibilita a originalidade da visão. A maioria das pessoas têm consciência de uma cultura, um cenário, um país; os exilados têm consciência de pelo menos dois desses aspectos, e essa pluralidade de visão dá origem a uma consciência de dimensões simultâneas, uma consciência que - para tomar emprestada uma palavra da música - é contrapontística."

(Edward Said)

Qual a originalidade presente na visão de um artista exilado? Quais as marcas deixadas na sua criação devido à sua condição de exílio? Em que medida a experiência do exílio influencia no processo criativo? De que forma opera a consciência do artista no momento da criação e como ela se manifesta no mundo?

Questionamentos como esses acabam surgindo quando o objeto de análise é a obra de Alice Brill. Alemã judia nascida no início do século XX, Brill chegou ao Brasil ainda jovem fugindo do cenário de guerra iminente que se desenrolava no seu país de origem. Foi em terras brasileiras que a jovem cresceu, amadureceu e veio a fazer parte de uma importante geração de artistas que contribuíram para o desenvolvimento e o aprimoramento da arte fotográfica no país durante os anos 1950.

A trajetória singular de Alice Brill exerceu forte influência sobre o seu processo criativo o que acabou deixando à mostra, para um observador mais atento, os traços de sua jornada e de sua forma de ver o mundo. Para melhor compreender a obra da artista e a sua experiência singular, o presente capítulo faz uma breve e importante exposição sobre o exílio e o processo de construção de identidade pelo qual o exilado passa ao longo de sua vida. Para tanto, foram utilizadas as autobiografias de dois intelectuais que passaram, eles mesmos, pela experiência do exílio e que optaram por deixar registradas as suas indagações pessoais acerca do 
tema. Uma breve biografia de Alice Brill é apresentada em seguida com particular ênfase ao percurso de seu exílio e a sua vida no Brasil.

\subsection{Quem foi Alice Brill}

A trajetória da artista plástica e fotógrafa alemã Alice Brill esteve ligada a um caminho plural, ou seja, possui influências tanto da Alemanha, país de origem, quanto brasileira. Sua obra relaciona-se ao movimento modernista dos anos de 1940 a 1950 no Brasil e sua trajetória nos permite compreender as histórias desenvolvidas nesse fluxo de imigração e as consequências do exílio causadas pelo antissemitismo.

Para a análise da vida e obra de Brill é necessário compreender a sociedade em que a artista se encontrava, sua formação acadêmica e os seus trabalhos como fotógrafa. Através da junção desses pontos é possível ter a percepção ampliada sobre os movimentos culturais e políticos vividos pela artista. Para conhecer sua trajetória, um importante trabalho é a monografia escrita pela jornalista Daniela Alarcon, denominada "Diário íntimo: as fotografias de Alice Brill"3, orientada pelo professor Boris Kossoy, da Universidade de São Paulo (USP). A vida de Alice Brill é traçada de forma cronológica pois a monografia começa tratando de sua vida na Alemanha e termina com as suas obras no Brasil. O trabalho é uma importante fonte para compreender o trajeto do exilio feito por Brill pois Daniela Alarcon teve acesso a cartas e materiais privados da artista, além de entrevistas que ela fez com a fotógrafa.

Alice Brill nasceu na Alemanha em 13 de dezembro 1920, na cidade de Colônia. Seus pais eram o artista plástico Eric Brill e a jornalista Marte Brill que se separaram quando ela tinha apenas um ano de idade, em função disso, ela passa a infância com a avó materna e com a mãe. Tanto sua mãe, Marte Brill, quanto seu pai, Eric Brill, eram de famílias judias e, mesmo não praticando a religião, eles sempre estiveram atentos a questões relacionadas ao judaísmo, como demonstram as diversas viagens feitas por Eric Brill a Palestina e a pesquisa de Marte Brill, na Espanha, sobre

os Sefardistas. ${ }^{4}$ As viagens feitas por Eric Brill são comentadas por Alice Brill em

\footnotetext{
${ }^{3}$ ALARCON, Daniela. Diário íntimo: as fotografias de Alice Brill. São Paulo:: 2008.

${ }^{4}$ Sefardistas são judeus espanhóis expulsos do país no final do século XV.
} 
dois momentos distintos: nas entrevistas concedidas a Daniela Alarcon e na introdução do catálogo da exposição feita por Brill com as obras de seu pai. Apesar de Eric Brill possuir telas com pinturas relacionadas a essa região, são poucas as informações sobre os motivos que o tenham levado a realizar essas viagens.

Alice Brill e sua mãe passaram a maior parte dos anos de 1920 na cidade de Hamburgo, uma cidade com cerca de 20 mil judeus, e que possuía um ambiente cosmopolita. Em 1920, o Partido Nacional Socialista apresentou, em Munique, um programa antissemita, que determinava os requisitos para se tornar um cidadão alemão, Alice Brill não se encaixava nos requisitos por ser de origem judaica. Esta década também foi intensa para a vida particular da artista e de sua mãe pois, em virtude do trabalho de jornalismo de Marte Brill, muitas viagens aconteceram. Em 1931, Marte Brill foi demitida da radio onde trabalhava, tentando empregar-se em outros jornais até 1933. Com a ascensão do nazismo, foi alertada pelos amigos da necessidade de deixar a Alemanha já que o seu trabalho em rádio a deixou muito visada por sua militância feminista e de esquerda.

Em março de 1933, Alice e Marte Brill viajam para a ilha de Maiorca, na Espanha. ${ }^{5}$ Alice Brill sai da escola e, para não perder o ano letivo, a professora pede que ela faça um diário sobre sua viagem, descrevendo aspectos culturais e políticos dos lugares que ela visitasse. Durante este trajeto ela começa uma narrativa singular sobre o exílio. Alice Brill ganha do seu pai uma câmera fotográfica e a partir de então, começa a registrar as cidades por onde passou fugindo do nazismo.

Eric Brill também registrava, por meio de fotografias, as cidades que visitava e Alice Brill tem conhecimento dessas fotografias somente após sua morte. Encontrando com sua avó em Nova York, teve a possibilidade de receber os pertences de seu pai Eric Brill, dentre eles estavam muitas fotografias que serviram de inspiração para sua profissão como fotógrafa. Apesar de ter concluído sua tarefa escolar ainda na Espanha, Brill não abandonou a câmera e registrou todos os lugares por onde passou durante o tempo em que esteve se deslocando.

Ao longo de todo o percurso, ela fez registros fotográficos, totalizando 200 fotografias que narraram esse trajeto. Essas imagens não serão analisadas aqui, mas

\footnotetext{
${ }^{5}$ ALARCON, Daniela. Op. cit., p.51.
} 
ele traz à tona a riqueza de um material singular, não só pela questão política que circundava Alice Brill, mas também por se tratar de uma narrativa imagética, onde ela utiliza o recurso da fotografia para demonstrar os seus sentimentos e as experiências vividas naquele momento.

Há também outra característica única, pois diário imagético Alice Brill apresenta a sua experiência nos três países em que passou (Espanha, Itália e Holanda) antes de chegar ao Brasil. Essa narrativa deixa claro não só a luta contra o antissemitismo, mas também como ela interpretou suas experiências em cada um desses países. Um exemplo dessa narrativa é o poema abaixo feito por Alice Drill ao longo de suas viagens e anexado ao diário. Nele fica explícito a vontade de ter um lugar onde ela possa estabelecer uma moradia, sua perspectiva sobre o mundo e também sua busca pela paz.

Grande é o mundo, A pátria, pequeninha, O lugar que eu gosto, Lá eu quero viver, com você, minha mãezinha!

Lá construímos uma casa no mar, E nenhuma saudade vai nos alcançar.

Lá a paz sua vitória celebrará

E nunca, nunca Guerra haverá!

Lá também vivem bem os animais, que um disparo não ouvem jamais.

Quando então se levanta a lua sobre o mar,

Eis que somos felizes, felizes sem parar!

E desde as galáxias resplandecentes

Chegam milhares de estrelas cadentes, Elas parecem na água afundar, como se fossem também se afogar. E no terraço, que a gente já pode ver, 
Seu mais lindo livro vai aparecer!

No qual virá seu fiel coelhinho

Sem pedir licença enfiar o focinho

Porque ele com fotos quer te agradar. ${ }^{6}$

Alice Brill não é a única a narrar sua trajetória. Marte Brill também escreve um livro sobre o trajeto de fuga das duas da Alemanha, a experiência que vivenciaram e como foi o percurso até a chegada ao Brasil. O livro se intitula "Der Schmelztiegel", originalmente foi escrito em alemão, mais tarde traduzido para o português pela filha de Alice Brill, Inês Czepski, mas nunca foi publicado. Há uma cópia do livro na Alemanha no arquivo de exílio da Biblioteca Alemã. O livro é uma narrativa romanceada, em que Alice Brill se chama Mirian e todas as pessoas que fizeram parte deste percurso de exílio tiveram seus nomes trocados. Daniela Alarcon chama atenção em seu livro para as dissonâncias entre o relato de Marte Brill e Alice Brill, como por exemplo o percurso feito para chegar a Espanha:

"Alice escreve em suas memórias que as duas chegaram em Florença no final de setembro de 1933, enquanto em "Der Schmelztiegel” a data indicada é agosto do mesmo ano. Os dois relatos divergem também em outro ponto: Marte afirma que a viagem de Gênova a Florença foi feita de trem; para Alice, teria sido de ônibus."7

Ao chegar na Espanha, em 1933, sua mãe iniciou uma pesquisa sobre os Autos da Inquisição espanhola que documentam as perseguições a judeus marranos levadas a cabo na ilha durante o século XVII. ${ }^{8}$ Ainda em 1933, elas seguiram para a Itália, pois Marte Brill não conseguiu emprego na Espanha e decidiu se mudar para Florença por imaginar que haveria maior possibilidade de empregos; Marte Brill já tinha morado na Itália e acreditava que lá elas teriam melhores condições, porém o que ela

\footnotetext{
${ }^{6}$ Poema escrito em alemão por Alice Brill, em seu diário de viagem. O poema foi traduzido por ThiagoScarelli..

IBIDI. P. 85

${ }^{7}$ ALARCON, Daniela. Op. cit., p.58

${ }^{8}$ Idem, p.57.
} 
encontrou foi uma Itália imersa no fascismo. Não encontrando trabalho, precisou deixar Alice Brill em um orfanato para crianças judias, em seu livro ela narra essa decisão:

"Os quartos das crianças eram brancos, as salas de trabalho claras e ensolaradas e havia até - milagrosamente - aquecimento central. Isto fechou a questão Miriam [Alice] não passaria mais frio". 9

$\mathrm{Na}$ Itália sofreram por sua condição de exiladas e, principalmente, por serem judias. Não vendo outra saída, Marte Brill decidiu voltar a Hamburgo, pois tinha recebido uma carta do editor chefe da revista em que trabalhava oferecendo uma passagem para um país da América do Sul, o Brasil.

Em 1934, elas chegaram a cidade de Hamburgo, que encontrava-se completamente diferente daquela que tinham deixado em 1933, segundo a própria Alice Brill: "A cidade tinha uma aparência estranha, rapazes e moças marchavam em uniformes nazistas entoando canções nazistas, e todas as paredes estavam cobertas de propaganda. "10 Lá, Alice Brill foi entregue ao pai, pois sua mãe estava organizando a vinda dela para o Brasil. Durante esse período, ela foi para a Holanda e ficou morando com a irmã de seu pai, aprendeu a língua holandesa e frequentou a escola até sua partida para o Brasil.

Marte Brill chegou ao Brasil e começou a trabalhar como secretária, enquanto Alice Brill permanecia com o pai na Holanda. Seis meses após sua chegada, ela conseguiu organizar a documentação da filha para a vinda dela e de Eric Brill, embarcando em um porto francês para o Brasil. Brill descreveu a viagem como:

“(...) uma jornada terrível. Eu estava chocada com a situação dos imigrantes miseráveis que quase não tinham pertences, alojados no convés do navio. A comida era escassa e muito pobre e tinham insetos em nossa pequena cabine" $" 11$.

\footnotetext{
${ }^{9}$ Ibidem, p.60.

${ }^{10}$ ALARCON, Daniela. Op. cit., p.60.

${ }^{11}$ Idem, p.64
} 
Chegaram ao Brasil pelo porto do Rio de Janeiro e ficaram instalados na ilha de Paquetá durante seis meses por conta dos contatos de trabalho que Eric Brill possuía. Após esse período, os dois vão para São Paulo ao encontro de Marte Brill.

O pai de Alice Brill voltou para a Alemanha em 1936, pois não se adaptou ao Brasil. Lá ele foi preso duas vezes: a primeira em 1937, ficando preso até 1941. Em liberdade, Eric Brill tentou fugir para a Rússia; e, pela segunda vez, é preso ainda em 1941 sendo levado para Riga, capital da Letônia, ficando no campo de concentração de Jungfernhof. Alice Brill recebeu, em 1946, apenas um telegrama avisando que seu pai estava preso, ela só foi descobrir o que de fato tinha ocorrido em 1947, em Nova York, quando sua avó relatou que Eric Brill tinha morrido em $1944 .^{12}$

As compreensões sobre a experiência que Eric Brill viveu e a de Alice Brill e Marte Brill são diferentes, pois Eric Brill não se adaptou a nova realidade no Brasil e assim retornou a Alemanha. Marte Brill e Alice Brill apesar de todas as dificuldades de adaptação em um novo país conseguiram ultrapassar as adversidades e transformar a realidade em que elas viviam. Portanto, há dois tipos de experiências de exílios, como a historiadora Silvana Jesen descreve em seu artigo "Exílio e Historia Reciente. Avances y perspectivas de un campo em construción”. Em suas palavras: "será fundamental diferenciar nitidamente "estar em El exílio" de "sentir se exilado"13. Desta forma, Alice e Marte Brill compreende que experiência de exílio traz a possibilidade de uma nova visão de mundo, ou seja, elas re-significaram a experiência e encontraram na arte um ponto de apoio; no caso de Marte Brill na Literatura e Alice Brill na Fotografia e nas Artes Plásticas.

\subsection{Alice Brill no Brasil}

Alice Brill sempre esteve em contato com arte, apesar de ter trabalhado como secretária em empresas privadas, livrarias e como professora. Aos 16 anos começou a

\footnotetext{
${ }^{12}$ ALARCON, Daniela. Diário íntimo. A fotografia de Alice Brill. São Paulo:2008. ${ }^{13}$ JENSEN, Silvana. Exílio e Historia Reciente. Avances y perspectivas de un campo enconstrución. Aletheia, vol 1, número 2, mayo 2011, p.2.
} 
estudar com o pintor e amigo de seu pai Paulo Rossi Osir ${ }^{14}$. Dessa experiência, Alice Brill recebe várias influências sendo a maior delas o valor dado a técnica que pode ser observada nas suas pinturas de batik e na fotografia. Paulo Osir funda em 1940 a Osirarte, grupo que tinha como foco o trabalho em azulejos para recuperar elementos da arquitetura colonial. ${ }^{15}$

Durante a década de 1940, Alice Brill também teve como professores a pintora húngara Yolanda Mohalyi e o pintor Aldo Bonadei. Bril é apresentada por Paulo Osir ao grupo Santa Helena, onde se reuniam pintores que em sua grande maioria eram de origem italiana, como por exemplo Volpi, Mario Zanini, Francisco Rebolo entre outros. O grupo se formou em 1934, com a mudança do ateliê de Rebolo para o Palacete Santa Helena, que deu origem ao nome do grupo. Eles se reuniam nos finais de semana pois, por serem de origem humilde, os seus componentes trabalhavam no ateliê apenas de forma parcial, não sendo a pintura o único trabalho que exerciam. No livro escrito por Alice Brill sobre Mario Zanini, intitulado: "Mário Zanini e seu Tempo"16, onde ela discute a obra do pintor e a importância do grupo Santa Helena.

Alice Brill traça um paralelo entre os modernistas da semana de 22 e o grupo Santa Helena considerando que a principal diferença estava na questão financeira do segundo grupo, onde a maioria dos artistas eram trabalhadores e não podiam se entregar de forma total a arte. Segundo Brill:

"Os artistas do Santa Helena e aqueles que os frequentavam eram, em sua maioria, autodidatas, como já foi referido, desde o didatismo puro de Alfredo Volpi, que aprendeu exclusivamente na prática, até a formação parcial ou completa, (...), tendo repúdio ao academicismo e a valorização do aprendizado técnico artesanal."17

\footnotetext{
${ }^{14}$ Paulo Rossi Osir era pintor e arquiteto (1890-1959), possuia uma carreira consolidada quando esteve com Alice Brill. Sua formação vem de escolas italianas, pois sua família tinha origem italiana. Defendia a modernidade sempre com ênfase na técnica.

${ }^{15} \mathrm{O}$ trabalho mais conhecido do grupo foi a decoração do Ministério de Educação e Saúde Pública, o Edifício Capanema, projetado por Oscar Niemeyer e construído entre 1937 a 1943 no Rio de Janeiro. A Osirarte encerra suas atividades em 1959.

${ }^{16}$ BRILL, Alice. Mário Zanini e seu tempo. São Paulo: Editora Perspectiva, 1984.

${ }^{17}$ Idem, p.39.
} 
Brill se aproxima do grupo não só pelo estilo artístico que tinham como característica, mas também pela sua própria trajetória pessoal.

Outro ponto que Alice Brill descreve como sendo uma marca do Santa Helena era em relação a sua composição, formado em sua maioria por imigrantes ou filhos de imigrantes. Brill fala em seu livro sobre Mario Zanini que a importância do artista estava ligada à sua forma de expressão. Destaca também uma falta de formação acadêmica dos artistas, portanto agiam intuitivamente; para ela era uma forma única de ver a arte. Alice Brill segue este princípio como ela própria cita no livro:

"Posso citar meu pai, o pintor Eric Brill, que desprezando os cursos de arte pelos quais passou rapidamente em Frankfurt e Berlim, por volta de 1919-20 preferiu deixar-se guiar pela própria intuição, sempre atento aos ensinamentos da natureza que desejava a interpretar da sua maneira. Não o revi depois de 1936, quando deixou o Brasil para retornar a Europa, depois de uma estadia breve, mas o que ele disse marcou o meu caminho de artista: de nunca seguir qualquer "ismo", numa atitude de recusa a qualquer influência, e de fidelidade a si mesmo" $" 18$.

Dentre os diversos grupos que nasceram ao longo desse período, o grupo Santa Helena exerceu uma forte influência na vida artística de Alice Brill. Esse vínculo que Brill possui com este grupo é demonstrado por ela no livro sobre o pintor Mario Zanini,

Portanto, ao longo de toda a sua carreira como artista, em apenas dois momentos, Alice Brill se dedica aos estudos vinculados a arte. $\mathrm{O}$ primeiro é com o grupo Santa Helena da qual participou e que será referência ao longo de sua vida e em seus estudos acadêmicos, como exemplo sua dissertação de mestrado que foi sobre o pintor Mario Zanini e que logo se transformou em livro. Em um segundo

\footnotetext{
${ }^{18}$ BRILL, Alice. Mario Zanini e seu tempo. São Paulo: Editora Perspectiva, 1984, p.27.
} 
momento foi sua ida para a universidade americana onde aprendeu a técnica de fotografar.

Durante esse período Alice Brill enfrentou problemas no Brasil por ser alemã. O governo de Vargas, em 1942, intensifica sua política contra a imigração e cria leis que restringem a circulação dentro do território brasileiro aos cidadãos de origem japonesa, italiana e alemã. Por conta das restrições impostas pelo governo, Brill precisava de autorização para qualquer viagem feita dentro do Estado de São Paulo, a partir de um prontuário ela recebia uma autorização para fazer suas viagens. Os prontuários estão arquivados no DEOPS/SP e existem vários deles expedidos por Alice Brill, entre eles está o pedido de uma viagem a Itanhém, no dia 10 de março de 1945. No documento possui não só o pedido de Brill para a viagem, mas também seu país de origem, seu endereço e quantidade de dias que pretende se ausentar da cidade de São Paulo. Ao analisar o prontuário fica claro como as políticas do governo de Getúlio Vargas estavam restringindo a circulação de pessoas que não possuíam nacionalidade brasileira. Como pode ser analisado no documento a seguir. 


\section{Quadro 1: Prontuário expedido no dia 10 de março de 1945.}

Bxmo.Snr, Dr. Delegado Da Ordem Polyts Palo A repuerent foderá DEL, OE ORO.POL.T SOCIAL PROTOCOLO GERA. 20 MAR 1945 Guichet N: $663 \mathrm{M}$

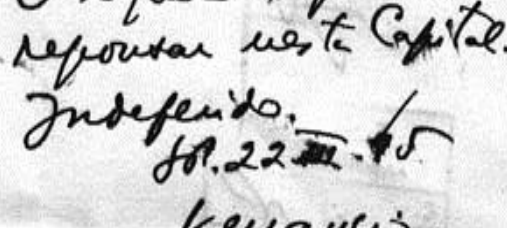

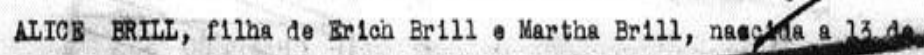

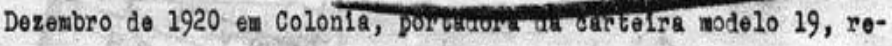
sistro geral n 560.744 , reglatro n 30.383 , residente á al. Rocha Azeredo, 951, Nesta, querendo fazer una vlagea de repouso á

Itanhaen, vên pedir-vos wul respeltuosamente dar 11aença para a exped1 f̧̃o do respetivo salvo conduto. Em tempo:Permanencia de 10 dias

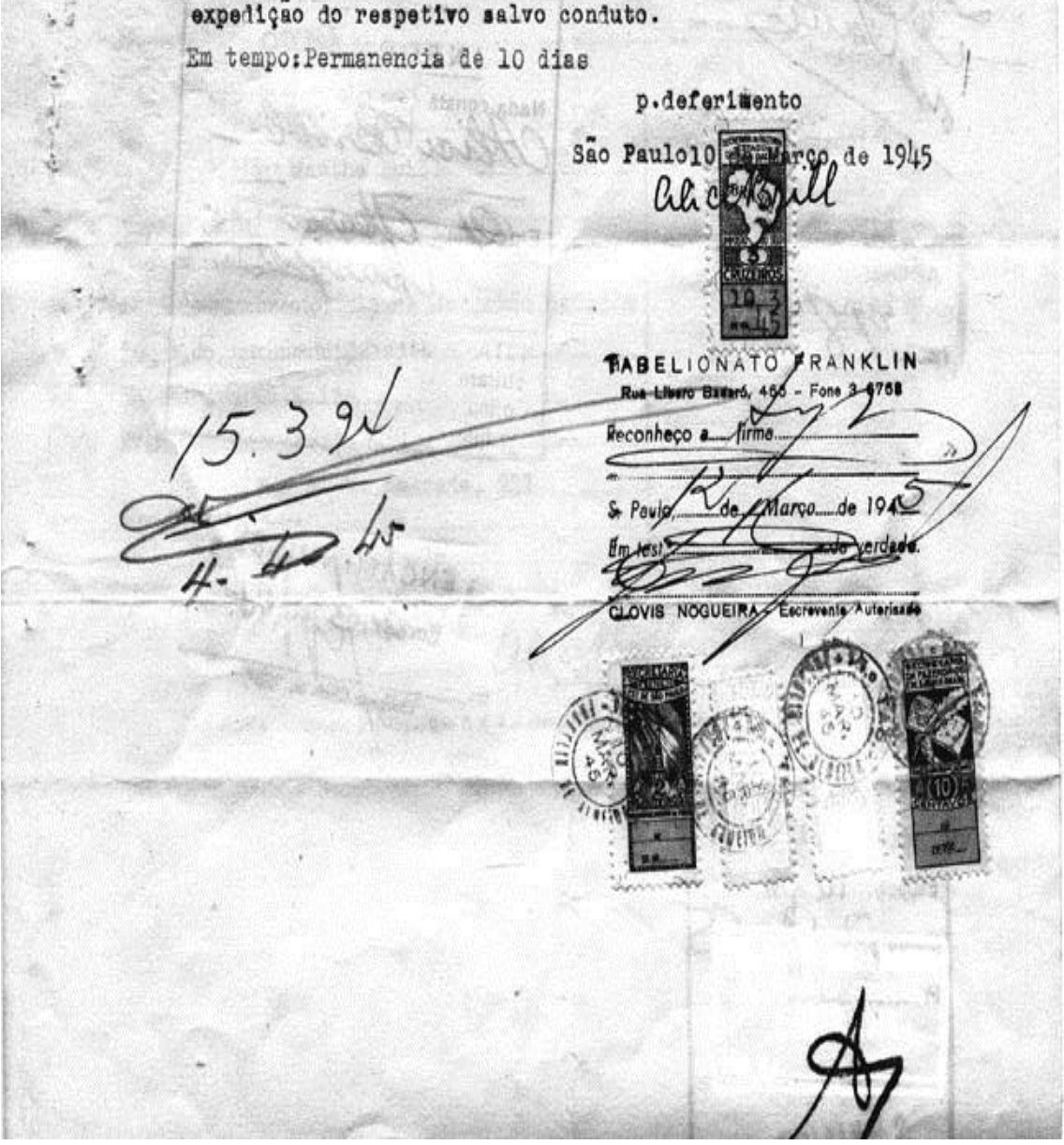

Fonte: DEOPS/SP 
Nesse período, Alice Brill trabalhava como secretária de uma companhia inglesa, porém, com o início da guerra, ela perde o emprego. Segundo Alice Brill: “ $a$ guerra estava se aproximando e quando ela começou, eu fui demitida por ser considerada cidadã alemã! Eu era agora inimiga dos ingleses, apesar de os alemães terem há muito cancelado nossa cidadania. Eu me senti traída e desamparada". ${ }^{19}$ Nesses dois momentos fica claro como Brill não possui uma pátria. Por não ser brasileira, ela necessita de autorizações para suas viagens e, por ser considerada alemã, apesar de não poder viver na Alemanha, ela é demitida de seu emprego. É importante ressaltar como o contexto político e social da época acabam transformando, mesmo que de forma involuntária, a vida de Alice Brill.

Em 1946, Brill viajou para os Estados Unidos, com intuito de estudar arte na Faculdade de Artes da Universidade de Novo México em Albuquerque, através de uma bolsa que ela obteve na instituição judaica, a Fundação Hillel para Refugiados. Esse momento foi fundamental para a construção de sua carreira como fotógrafa e também para a construção de sua forma de criar e fotografar.

Durante este período, o seu nome apareceu em dois momentos distintos no jornal "New Mexico Lobo" que era publicado pela universidade: em $1946^{20}$ e $1947^{21}$. Alice Brill é citada em função de sua participação nos projetos ligados a arte na universidade. Lá em uma carta ela descreveu como se sentia:

“O problema é que vivo ainda no século passado... Quero aquela luta pela liberdade, aquelas colônias de artistas, aqueles artistas e poetas que se foram todos... [...] É horrível, pertencer a um mundo já morto, ainda moça. Compreendes?"22

Alice Brill encontrava-se em Nova York quando escreve esta carta, lá ela deparou com novas possibilidades de arte entre elas a fotografia, que será sua profissão na volta ao Brasil. O trecho desta carta dá a possibilidade de notar um

\footnotetext{
${ }^{19}$ ALARCON, Daniela. Diário íntimo. A fotografia de Alice Brill. São Paulo, 2008, p.97.

${ }^{20}$ University of New Mexico. "New Mexico Lobo, Volume 049, No 20, 12/6/1946." 49, 20 (1946). http://digitalrepository.unm.edu/daily_lobo_1946/44

${ }^{21}$ University of New Mexico. "New Mexico Lobo, Volume 049, No 44, 4/11/1947." 49, 44 (1947). http://digitalrepository.unm.edu/ daily_lobo_1947/19

${ }^{22}$ ALARCON, Daniela. Diário íntimo. A fotografia de Alice Brill. São Paulo, 2008, p.136.
} 
sentimento comum entre as pessoas que passaram pela experiência de exílio. É possível perceber em todos um sentimento de passado utópico: não podendo confiar no presente e no futuro, acabam tornando o passado algo glorioso. Edward Said deixa claro esse sentimento:

"Por mais que tenham êxito, os exilados são sempre excêntricos que se sentem sua diferença (ao mesmo tempo que, com freqüência, a exploram) como um tipo de orfandade. Aqueles que realmente não têm lar consideram uma afetação, uma exibição de modismo de ver alienação em tudo o que é moderno. Agarrando-se à diferença como a uma arma a ser usada com vontade empedernida, o exilado insiste ciosamente em seu direito de se recusar a pertencer a outro lugar." ${ }^{, 3}$

De volta ao Brasil, Alice Brill encontrou São Paulo em plena transformação, o parque industrial crescia rapidamente financiado pelos lucros do café, consolidando uma sociedade urbano industrial. Retornando dos Estados Unidos, começou a trabalhar como fotógrafa. Como primeira experiência nesse campo, ela investiu em buscar contatos com a revista americana "Life", apresentando seu trabalho produzido em uma mina de carvão no sul do Brasil feita no ano de 1946, porém não recebeu nenhuma resposta.

Logo após essa tentativa, ela fez outra viagem a Corumbá (centro oeste do Brasil) com o intuito de fotografar as comunidades indígenas. Para isso ela participou de uma expedição organizada pela Fundação Brasil Central (FBC) que tinha o intuito de apresentar os trabalhos concluídos pela fundação para o deputado Café Filho ${ }^{24}$, porém, Alice Brill se decepcionou já que passou apenas duas horas em contato com os indígenas. Parte deste trabalho foi apresentado pela revista Habitat, onde a artista trabalhava.

A Habitat foi o principal meio de circulação das fotografias de Alice Brill. Ao longo da década de 1950 a artista participou de várias matérias publicadas pela revista e foi uma das que mais produziu fotografias para essa publicação. A revista foi editada e criada por Lina Bo Bardi e Pietro Bardi e tinha como objetivo trazer novas propostas para assuntos ligados a arte, arquitetura e cultura. Segundo Lina Bo Bardi:

\footnotetext{
${ }^{23}$ SAID, Edward. Reflexões sobre o exílio. São Paulo: Companhia das Letras, 2003, p.55.

${ }^{24}$ Café Filho (1899-1970) se tornaria Presidente do Brasil em 1954.
} 
"Habitat" significa ambiente, dignidade, conveniência, moralidade de vida, e, portanto, espiritualidade e cultura: é por isso que escolhemos para título desta nossa revista uma palavra intimamente ligada à arquitetura, à qual damos um valor e uma interpretação não apenas artística, mas uma função artisticamente social. "25

A revista Habitat teve sua circulação ligada ao MASP (Museu de Arte de São Paulo) e durante esse período, Alice Brill participa de atividades do MASP e do MAM, sendo uma das fundadoras do MAM.

A partir dos anos de 1960, Alice Brill se desvincula da "Habitat" para focar em seu trabalho com artista plástica. Nesse período ela começou a desenvolver pinturas em Batik e aquarela, passando a dedicar todo o seu tempo para as artes plásticas.

Em 1961 ela deu início a graduação em Filosofia na PUC-SP e logo depois fez sua pós-graduação em Arte pela Universidade de São Paulo, tornando-se, em seguida, professora universitária. Alice Brill, em suas pinturas, continua explorando os temas vinculados a metrópoles e suas consequências. Publicou, também, livros vinculados aos temas ligados a arte, entre eles "Mario Zanini e seu tempo" e "Samson Flexor". Alice Brill morre em 2013 deixando um acervo singular por abarcar diversos campos da arte e por sua experiência pessoal.

Portanto, neste capitulo relaciono o impacto da experiência de deslocamento como motor da construção de uma obra artística singular por compreender que esses deslocamentos transformam a subjetividade, já que alargam a compreensão sobre as diferentes culturas e modos de vida. A arte, para Brill, foi uma forma de demonstrar suas percepções sobre as novas experiências; elas são o resultado da adaptação a novas culturas, possibilitando uma experiência única.

Edward Said, ao falar sobre sua historia, revela através do titulo fora do lugar um mote intencional para este trabalho, sua busca por pensar e escrever sobre o tema é algo visto em outros autores que passaram também por esse tipo de experiência, no caso aqui de Vilém Flusser, que foi obrigado a deixar seu país e se refugiar no Brasil. Esse tipo de experiência provoca uma sensação de desconforto sobre a realidade, não

\footnotetext{
${ }^{25}$ Lina Bo Bardi - 3 edição SP: 2008. Imprensa oficial e Instituto Lina Bo Bardi, p.64.
} 
há algo seguro e nem familiar, as questões externas, ligadas ao mundo se tornam questões mais complexas. Isso se transforma pelo olhar que o exilio proporciona a esses autores, esse olhar e essa compreensão sobre o mundo culmina em trabalhos autorais de escrita ou de artes plásticas. Vilém Flusser descreve esse sentimento em seu livro, para o autor:

"Em suma, sou apátrida, porque em mim encontram-se armazenadas várias pátrias. Isso se revela diariamente em meu trabalho. Sou domiciliado em no mínimo quatro idiomas e me vejo desafiado e obrigado a traduzir e retraduzir tudo o que tenho a escrever. (...) nos reconhecemos então não como marginais mas sim como vanguarda do futuro."26

As dissonâncias na vida de Alice Brill, são um importante condutor para repensar a carreira e a vida da artista. Elas surgem com as escolhas feitas por Alice Brill que sempre tensionam e colocam a prova as formas de pensar. Dentre elas estão a escolha pela fotografia e o caminho feito pela artista para se tornar fotógrafa. Como mencionado, Alice Brill veio de uma família de artistas, sua vida sempre esteve de alguma forma ligada a arte. Durante um longo período, Alice Brill foi integrante do grupo Santa Helena mas a fotografia surge como uma opção para a artista quando ela recebe uma bolsa de estudos nos EUA, lá ela aprende a fotografar e também desenvolve o estudo sobre Arte. Parece evidente nesse processo de aprendizagem e contato com a fotografia é a forma como isso acontece. Como citado no início, as dissonâncias em sua vida são muitas e o que fica marcado são os trânsitos existentes no percurso de vida de Brill.

Apesar de ser alemã e ter tido contato com a arte brasileira, a formação de Alice Brill é feita por uma universidade americana demonstrando assim o trânsito de ideias que a artista encontra e a que transforma sua visão sobre o que ela fotografa.

Outra característica marcante na construção de sua forma de fotografar está no grupo que Alice Brill frequentava ao longo dos anos de 1950 e que foram, em sua maioria, formados por artistas e intelectuais exilados ou emigrantes, o que reforça a pluralidade de nova ideias. É importante ressaltar o ambiente e a forma como a artista

\footnotetext{
${ }^{26}$ FLUSSER, Vilém. Bodenlos, uma autobiografia filosófica. São Paulo: Annablume, 2007, p.296.
} 
constrói sua obra. Para Alice Brill, isso foi feito de forma múltipla e singular, ela não possui um caminho linear e sim uma pluralidade de referencias que transformam sua visão de mundo e consecutivamente sua arte.

\subsection{Alice Brill e a experiência do exílio}

O século XX foi marcado por diversos conflitos étnicos, culturais e políticos que se manifestaram de forma violenta. Dentre eles, aqueles que mais se destacaram foram os eventos da Primeira Guerra Mundial (1914-1918) e da Segunda Guerra Mundial (1939-1945). As duas guerras compõem um cenário único de violência que até então não havia sido experimentado na história da humanidade. Esses conflitos alcançaram proporções inéditas e se transformaram em guerras de massa no sentido de que usaram, contaram com enorme contingente humano de todos os continentes e transformaram os civis e a vida civil nos verdadeiros alvos estratégicos ao fazer uso de tecnologias massivas que atingiram a população nunca antes ocorrido na historia.

Nesses conflitos impessoais, embaixo dos bombardeios aéreos não estavam as pessoas que iam ser queimadas e evisceradas, mas somente alvos que deviam ser atingidos ${ }^{27}$. Além das vidas perdidas, um dos maiores impactos das duas grandes guerras na sociedade global foram os deslocamentos forçados de pessoas e a consequente criação de novas identidades.

Ao longo dos anos 1930 e 1940, verificou-se um grande fluxo de migração com a saída de muitos europeus dos seus países de origem para outros lugares. Parte desse fluxo foi composto, em particular, por um grupo étnico específico e foi provocado pela ascensão do regime nazista na Alemanha e, consequentemente, pela criação de políticas antissemitas que forçaram mais de 500 mil judeus a seguir pelo caminho de exílio. A América Latina foi um dos principais destinos desses exilados,

\footnotetext{
${ }^{27}$ As reflexões acerca do século XX e, em particular, sobre os impactos da Primeira e da Segunda Guerra Mundial foram embasadas nas ideias do intelectual Eric Hobsbawm. Para saber mais, ver: HOBSBAWM, Eric J. Era dos extremos: o breve século XX: 1914-1991. São Paulo: Companhia das Letras, 1995.
} 
sendo o Brasil o segundo país a receber mais expatriados ${ }^{28}$. Entre os exilados que aqui chegaram identificamos um número significativo de intelectuais e artistas que acabaram se tornando fundamentais para a construção dos movimentos modernistas brasileiros dos anos 1940 e 1950. Alguns deles deixaram relatos contundentes sobre as suas experiências de exílio.

Os relatos desses autores expatriados da segunda metade do século XX apresentam reflexões importantes sobre a formação de identidades e as dinâmicas migratórias, além de críticas políticas e sociais ao mundo contemporâneo. A análise desse tipo de documento se apresenta como uma excelente oportunidade para entender a experiência do exílio. Entretanto, antes mesmo de examinar um relato que se enquadre dentro do perfil mostrado - um exilado europeu de origem judaica que no Brasil contribuiu para o campo intelectual e artístico - é preciso abordar conceitos e reflexões sobre o exílio de forma geral. Para tanto, poucos autores foram tão eloquentes quanto o crítico literário Edward Said (1935-2003).

O exílio compreendido no abandono de sua terra natal para outro local, não expressa os desdobramentos que esse percurso provoca na pessoa que teve essa experiência. O exilado portanto, amplia sua visão de mundo, passa a criar novos significados para sua vida e encontra na arte e na escrita sua verdadeira terra. $\mathrm{O}$ exilado enxerga alternativas de se colocar e de reestruturar sua identidade, que foi perdida ou descontruída através de reflexões e expressões nos campos da arte e da linguagem.

Said refletiu sobre questões que extrapolam o campo literário e contribuíram para a compreensão sobre a construção de identidades na modernidade e deslocamentos contemporâneos. A sua própria origem e trajetória particular serviram de base para suas reflexões e fornecem importantes ponderações que são válidas para a presente pesquisa.

Edward Said nasceu em Jerusalém numa família de árabes cristãos e tinha cidadania norte-americana herdada de seu pai obtida após o serviço militar prestado durante a Primeira Guerra Mundial. Ele cresceu entre Jerusalém, Líbano e Cairo, até que, em 1947, sua família se mudou definitivamente para o Egito devido aos 
negócios do pai e às tensões geradas pela resolução da Organização das Nações Unidas de dividir a Palestina para a criação do Estado de Israel.

No Cairo, ele frequentou prestigiosas escolas particulares inglesas e, aos 16 anos, foi mandado para uma escola particular nos Estados Unidos. Foi em território norte-americano que ele prosseguiu com seus estudos e, em 1963, se tornou professor de literatura comparada e teoria literária na Universidade de Columbia. Tornou-se um proeminente intelectual no âmbito de estudos culturais e foi fundador do campo acadêmico de estudos pós-coloniais.

Dentre sua vasta obra, destaca-se a obra Fora do Lugar $^{29}$, uma autobiografia publicada em 1998 muito importante para a discussão sobre os estudos do exílio. Said tem como intuito analisar sua própria experiência durante as transições de lugares feitas ao longo de sua vida e como esses deslocamentos foram importantes para a construção de sua identidade. O autor defende uma fluidez identitária no lugar de algo sólido, concreto e coerente ao afirmar que "às vezes me sinto como um feixe de correntes que fluem. Prefiro isso à ideia de um eu sólido, à identidade a que tanta gente dá tanta importância",30.

À essa defesa, podemos acrescentar suas reflexões presentes no artigo publicado pela primeira vez em 1984 intitulado Reflexões sobre o exílio ${ }^{31}$. Nesse artigo, Edward Said discute como o deslocamento pode transformar e alargar os olhares acerca da realidade de quem vive essa experiência, pois ele afirma que a transição entre países e culturas diferentes fazem com que cresça a percepção sobre as “realidades simultâneas", possibilitando assim compreender a pluralidade cultural e política presente no mundo.

Ao discutir a experiência do exílio, Edward Said aponta para a presença de uma dualidade permanente dentro daquele que vive esta situação que não seria nem positivo e nem negativo, mas uma experiência única que permite um alargamento da compreensão sobre o mundo. E essa experiência única não se trata de uma escolha, pois o autor defende que ela é o resultado de um processo em que o indivíduo teve que deixar sua pátria à força.

\footnotetext{
${ }^{29}$ SAID, Edward. Fora do Lugar. São Paulo: Companhia das Letras, 2004.

${ }^{30}$ SAID, Edward. Op. cit., p.429.

${ }^{31}$ SAID, Edward. Reflexões sobre o exílio. São Paulo: Companhia das Letras, 2003.
} 
Porém, ao viver essa experiência, o indivíduo pode ganhar - se souber tirar proveito dessa situação - um novo olhar sobre a realidade vivida que passa agora a ter um novo significado e todos os acontecimentos externos acabam se refletindo na própria identidade do sujeito. Afirma ele que "no fim das contas, o exílio não é uma questão de escolha: nascemos nele, ou ele nos acontece. Mas, desde que o exilado se recuse a ficar sentado à margem, afagando uma ferida, há coisas a aprender ${ }^{32,}$.

O exílio traz à tona uma nova imagem do país que em se vivia, assim como transforma o entendimento do indivíduo sobre a sua própria história no país ou países em que passou a viver. Embora a experiência possa ser dolorosa, o indivíduo começa a resgatar novas formas de compreender o mundo e a si mesmo. Assim a literatura e as artes de forma geral são caminhos percorridos para se criar uma realidade completamente nova que permita ao indivíduo compreender o mundo à sua volta e que acabam expondo uma escrita e uma visão que são singulares e que ultrapassam as noções enrijecidas e já pré-estabelecidas de pátrias e de nações.

O exílio seria uma vantagem ao intelectual, pois a sua posição privilegiada de ter vindo de outro lugar lhe permitiria "ver as coisas não apenas como elas são, mas como se tornaram o que são". Segue ele defendendo que:

“(...) isso significa observar as situações como contingentes e não como inevitáveis, encará-las enquanto resultado de uma série de escolhas históricas feitas por homens e mulheres, como fatos da sociedade construída por seres humanos e não como naturais ou ditadas por Deus e, por consequência, imutáveis, permanentes, irreversíveis" ${ }^{\text {,3 }}$.

Esse certo inconformismo do exilado se faz presente na sua construção identitária, pois ela torna-se mais fluida. Edward Said critica a noção de pertencimento a um único lugar e afirma ser uma ingenuidade pensar que cada indivíduo tem uma única identidade. Para ele, a identidade é construída por meio de vários fatores ao longo da história pessoal de cada um e está em constante mudança.

\footnotetext{
${ }^{32}$ SAID, Edward. Op. cit., 2003, p.57.

${ }^{33}$ SAID, Edward. Representações do intelectual: as Conferências Reith de 1993. São Paulo: Companhia das Letras, 2005, pp.67-68.
} 
Sendo mutável por natureza, a identidade não pode ser única e nem mesmo estar atrelada à uma única experiência de pertencimento à um espaço específico.

Edward Said se autodenominava um intelectual exilado e, para ele, esse termo referia-se a uma forma particular de olhar o mundo que não estava presa a conceitos pré-moldados, principalmente naquele que vê o conceito de nação como algo inflexível. O autor, portanto, ao longo de sua produção intelectual questiona o tempo todo esse conceito, analisando como ele foi construído e qual sua repercussão no cotidiano.

Esta sua visão singular sobre o mundo pode ser compreendida quando analisamos a sua própria vida e trajetória. Seu sobrenome árabe vinha acompanhado de um nome tipicamente inglês e embora frequentasse uma escola egípcia, o seu local de nascimento havia sido Jerusalém e seu passaporte era norte-americano. Tendo vivenciado o exílio e estando em trânsito por vários lugares, Edward Said teve que reconsiderar conceitos como nacionalidade, identidade, dentre outras questões para refletir sobre sua própria história.

Para o autor o exílio possui um duplo caminho pois apesar das questões negativas que o exílio traz à tona, como por exemplo, a perda da língua, as diferenças culturais, entre outras, ele também proporciona uma nova visão de mundo que ajuda o exilado a ter um alargamento das compreensões sobre o mundo que o cerca. Para Edward Said, o território que importa é o intelectual e não o social. Nesse sentido, o melhor lugar para o intelectual habitar não está relacionado com nações, mas sim pela sua produção literária. Portanto para o autor:

"O exilado sabe que, num mundo secular e contingente, as pátrias são sempre provisórias. Fronteiras e barreiras, que nos fecham na segurança de um território familiar, também podem se tornar prisões e são, com frequência, defendidas para além da razão ou da necessidade. $O$ exilado atravessa fronteiras, rompe barreiras do pensamento e da experiência",34.

\footnotetext{
${ }^{34}$ SAID, Edward. Op. cit., 2003, p.58.
} 
Apesar desses pontos positivos, o autor não deixa de reconhecer que o exílio pode trazer grandes problemas para a humanidade, como: tristeza, dor mutiladora da separação, perda, angústia, mudez, negação da dignidade e da identidade, punição política, solidão miserável, privação e banimento ${ }^{35}$.

O tema sobre exílio também é discutido no livro "Reflexões sobre o exílio", que foi lançado em 2003, onde Edward Said reúne diferentes textos ensaísticos relacionados as questões do exílio. No livro ele aborda temas ligados a literatura, música e política com o intuito de relacionar esses temas com o papel desenvolvido por pessoas que passaram por diferentes tipos de exílio. Portanto, o autor discute como o deslocamento pode transformar e alargar os olhares acerca da realidade de quem vive essa experiência. Segundo Edward Said, a transição entre países e culturas diferentes fazem com que cresça a percepção sobre as "realidades simultâneas", ou seja, compreendem a pluralidade cultural e políticas.

Compartilhando estudos vinculados ao tema do exílio, podemos citar o filósofo Vilém Flusser (1920-1991), intelectual que possui uma trajetória de vida em que as mudanças bruscas ocasionadas pelo exílio são pensadas e discutidas ao longo de sua obra. Em seu livro autobiográfico "Bodenlos" 36 , ele redige sua história e questiona certos posicionamentos que o ligavam a lugares em que viveu. O livro foi publicado em 1992, em alemão, não havendo uma cronologia específica para datar quando Flusser começou, realmente, a escrever sua autobiografia. Alguns deduzem que a primeira versão começou a ser escrita nos anos 70, logo após sua mudança para França, porém, como é comum em sua trajetória, os textos foram sempre redigidos em várias línguas e reescrito diversas vezes, dificultando assim uma cronologia detalhada de sua obra.

O título do livro "Bondelos", pode ser traduzido como "sem chão ou sem fundamento" e já demonstra uma sensação de instabilidade que acompanha todo o livro, onde o autor conta sua trajetória pessoal, as pessoas do seu convívio e suas profissões. O autor analisa criticamente todos esses fatores através de capítulos dedicados a uma discussão teórica sobre questões filosóficas que foram importantes

\footnotetext{
${ }^{35}$ SAID, Edward. Op. cit., 2003, pp. 46-60

${ }^{36}$ FLUSSER, Vilém. Bodenlos: uma autobiografia filosófica. São Paulo: Annablume, 2007.
} 
em seu caminho como intelectual. Todas essas discussões são apresentadas de forma singular, sem uma conexão direta entre um assunto ou outro, porém com um arranjo preciso que pode ser compreendido após a leitura completa do livro.

Assim como Edward Said, Vilém Flusser tem uma trajetória de vida marcada pelo exílio. Fugiu de Praga, na República Tcheca, em 1939, por ser judeu, veio para o Brasil, residindo em São Paulo até 1973, quando decidiu morar na França, em Robion. Em 1991, Vilém Flusser volta à Praga para uma conferência e acaba falecendo em sua cidade natal em decorrência de um acidente de carro.

No Brasil, foi um importante intelectual, apesar de não possuir uma formação específica. Foi professor na Universidade de São Paulo (USP), na Fundação Armando Alvares Penteado (FAAP) e no Instituto de Tecnológico da Aeronáutica (ITA), escrevendo durante esse período para o jornal Folha de São Paulo e para O Estado de São Paulo. Publicou mais de 30 livros em francês, português, alemão e inglês sendo um intelectual plural que discutiu temas ligados a arte, filosofia e fotografia. Flusser é um intelectual plural que discutiu temas ligados a arte, filosofia e fotografia. Um dos trabalhos que analisa a trajetória de Flusser é a tese de doutorado em História, "Exílio como forma", de Manuela Fantinato, a autora discute as formas de escrita de Flusser e sua variedade de assuntos tratados ao longo de sua trajetória como filósofo, pensador. Para Fantinato:

\begin{abstract}
"Trata-se de escrita que se propõe a articular o inarticulável, pois negocia e dialoga com a própria experiência do autor. Não apenas toda experiência é, em certa medida, inarticulável, mas especialmente a experiência de quem passou a vida negociando com as rupturas provocadas pela experiência de exílio e a ressignificação de referências que essa condição impõe." 37
\end{abstract}

A história de vida de Vilém Flusser possui muitas similaridades com a trajetória de Alice Brill pois ambos eram professores de filosofia e discutiam assuntos relacionados a arte, como a discussão sobre a obra do pintor romeno Samson Flexor. Vilém Flusser dedica um capítulo de sua autobiografia a esse artista enquanto Alice

\footnotetext{
${ }^{37}$ Fantinato, Manuela Rodrigues; Parada, Maurício Barreto Alvarez (orientador). Exílio como forma. Rio de Janeiro, 2018. 147 p. Tese de Doutorado - Departamento de História, Pontifícia Universidade Católica do Rio de Janeiro. Pag. 22
} 
Brill escreve um livro dedicado inteiramente à Samson Flexor e suas obras, do qual foi resultado de sua tese de doutorado, sob o título: "Samson Flexor- Do Figurativismo ao Abstracionismo." 38 neste livro referente a Samson Flexor, Alice Brill cita Flusser. Há uma ligação estreita entre eles que será discutida através do ponto de partida que transforma a vida dos dois, levando a construir um caminho singular, este mote é o exílio e a transformação que causou para o pensamento e o desenvolvimento de sua arte.

Assim como Edward Said, primeiro intelectual que foi apresentado para a discussão sobre a transformação no pensamento em decorrência do exílio, Vilém Flusser, em seu primeiro capitulo, discute a experiência da falta de fundamento, dando uma sensação de instabilidade, usando como exemplo a botânica. Ele descreve esta experiência como se fossem plantas sem raízes, ou seja, sem algo concreto que pudesse dar significado a sua trajetória. Para ele o termo "absurdo" expressa essa experiência, em suas palavras: "O termo "absurdo" significa originalmente "sem fundamento", no sentido de "sem raizes". (...) A tendência das flores sem raiz é o clima da falta de fundamento. O presente livro atestará tal clima. „39

Em todo livro Vilém Flusser discute esse sentimento e questiona suas decisões no âmbito profissional e pessoal demonstrando uma instabilidade construída a partir dos lugares que habitou e das diferentes culturas que ele conheceu. Essa instabilidade não é algo negativo, trata-se de um questionamento sobre conceitos que, em sua maioria, estão naturalizados no cotidiano. Um conceito discutido pelo autor é a noção de pátria, segundo o autor:

"Ele reconhece não apenas que cada pátria, a sua maneira, cega aquele que nela está intrincado (e, nesse sentido, todas as pátrias são parecidas), mas sobretudo que, somente após a superação desse enredamento, tornam-se-lhe acessíveis julgamentos, decisões e ações livres" ${ }^{\text {40 }}$.

\footnotetext{
38 Brill, Alice. Samson Flexor - Do Figurativismo ao Abstracionismo. São Paulo: EDUSP, 1990.

${ }^{39}$ FLUSSER, Vilém. Bodenlos, uma autobiografia filosófica. São Paulo: Annablume, 2007, p.19.

${ }^{40}$ Idem, p. 298.
} 
Esses dois autores percorrem caminhos que buscam compreender as narrativas de imigração ocasionadas pelas políticas do século XX. Em Edward Said ligadas ao colonialismo e no caso do Vilém Flusser relacionadas às políticas anti-semitas. Esse trânsito cultural é formado pela ligação entre diversos lugares que até então viviam geograficamente e historicamente separados. Além de lidar com o mesmo objeto de estudo, esses teóricos possuem em comum uma trajetória de vida migrante, onde o sentimento de não pertencimento se transforma em estudos e teorias que tentam abarcar a formação da modernidade. 


\section{Alice Brill e o meio artístico}

Como se construiu a trajetória de Alice Brill nos movimentos culturais dos anos de 1950 no Brasil? Como a fotografia se inseriu em museus e semanas de arte? Como foram formados os conjuntos fotográficos de Alice Brill? Como ela construiu sua carreira como fotógrafa?

No Brasil, as primeiras décadas do século XX foram um período de intensa transformação, no âmbito cultural, político e econômico. Na política, a década de 1930 foi muito relevante. A economia brasileira sofreu com o impacto da produção cafeeira e a quebra da Bolsa de Valores, em 1929, em Nova York. O início da Segunda Guerra Mundial e o fim da Primeira República deram início a novos embates políticos.

Outros processos como a migração e imigração, crescimento das cidades, as novas tecnologias, a expansão da indústria, o rádio, a imprensa ilustrada e o cinema, fazem dessa década um marco importante para compreender as dinâmicas sociais e culturais existentes no Brasil. As três décadas seguintes foram marcadas pelas disputas políticas com enfoque na figura do Presidente Getúlio Vargas que governou de 1930 a 1934 como chefe provisório, de 1934 até 1937 como presidente, de 1937 a 1945 a partir do golpe e depois entre 1951 e 1954, ano de sua morte.

Os debates ocorridos no cenário cultural durante as décadas de 1940 e 1950 no Brasil estavam vinculadas às discussões promovidas pelas vanguardas artísticas modernistas. As principais discussões deste grupo formavam-se no âmbito de identidade nacional e sua relação com a modernidade. É importante ressaltar que o modernismo no Brasil foi algo tardio, levando em consideração o movimento moderno como um movimento global, que teve impacto em outros países.

O conceito moderno possui uma ampla teia de significações que se sobrepõe, criando assim um termo complexo e fluido. Neste sentido, as discussões sobre a construção e o desenvolvimento do conceito são realizadas pelo crítico literário 
alemão Hans Ulrich Gumbrecht, professor de literatura comparada na Universidade Stanford, em seu livro "Modernização dos sentidos"

Neste livro, Hans Gumbrecht amplia a compreensão sobre o conceito de modernidade. Em sua teoria esse conceito pode ser percebido através de sobreposições de significados, que transformam o significado do conceito. O início dessa discussão sobre modernidade para o autor começa nos séculos XV e XVI em dois eventos: o primeiro relacionado à descoberta da imprensa e sua disseminação e, o segundo, à descoberta da América. Esses eventos ressignificam a compreensão sobre o mundo que até então possuíam significados e sentidos específicos. A partir de 1800, essa estrutura muda e a história, ou o real, ganha novos sentidos, que irão sendo ampliados e alterados gerando uma instabilidade. Neste sentido o autor discute que:

"Quem opera com problemas e conceitos como os de modernidade e modernização, períodos e transições de período, progresso e estagnação (...) não pode deixar de confrontar-se com o fato de uma sobreposição "desordenada" entre uma serie de conceitos diferentes de modernidade e modernização. Como cascatas, esses conceitos diferentes de modernidade parecem seguir um ao outro numa sequencia extremamente veloz, mas, retrospectivamente, observa-se também como se cruzam, como os seus efeitos se acumulam e como eles interferem mutuamente numa dimensão (difícil de descrever) de simultaneidade"42

A partir da discussão feita por Hans Gumbrecht, compreende-se que o modernismo possui diversas facetas. Neste trabalho o conceito será analisado através da fotografia, que entre os anos de 1940 e 1950 estava em grande expansão e discussão.

Denominava-se fotografia moderna, um estilo que nasceu no início do século XX na Europa e nos Estados Unidos e que chegou ao Brasil nos anos 1930. O espaço onde havia um debate mais intenso eram os Foto Clubes ${ }^{43}$. Nesses clubes as

${ }^{41}$ GUMBRECHT, Hans U. Modernização dos sentidos. São Paulo: Ed. 34, 1998.

${ }^{42}$ GUMBRECHT, Hans U. Op. cit., p.9.

${ }^{43}$ O Foto Clubismo surgiu na França e Inglaterra em torno de 1850. No Brasil, os primeiros clubes foram criados ao longo de 1930 no Rio de Janeiro e em São Paulo. Tinham como intuito a discussão e 
discussões circulavam em torno de uma nova atmosfera para a fotografia; o intuito dos novos fotógrafos eram romper com uma tendência pictorialista, ou seja, não desejavam reproduzir na fotografia os modelos de pinturas clássicas que até então eram utilizados para a produção das imagens.

Esse movimento buscava para a fotografia o status alcançado pelas outras artes. Suas principais características eram fotografias com enfoque nas cidades (urbanas), ênfase em assuntos contemporâneos e a utilização das artes gráficas e plásticas para a construção da imagem. Havia também uma busca pela técnica que trazia uma estrutura sólida para as novas formas de fazer arte, entre elas a fotografia.

Um dos grupos referência é o grupo Arte Nova que tinha como intuito romper com uma ideia de fotografia como mera reprodução e passa trabalhar técnicas que estão além da simples câmera e filme.

A busca por novas interpretações da vida cotidiana, fazem com que os fotógrafos modernos tenham uma sensibilidade aguçada sobre a realidade que os rodeia. Essa preocupação em retratar e dar significado a acontecimentos ocorridos no presente são a grande novidade na fotografia moderna. Ela, portanto, transforma os estilos de fotografia até então concebidos, saindo assim de imagens feitas em interiores de estúdios e expandindo seu olhar para outros objetos que não faziam parte do campo fotográfico.

O "belo" passa a ter um papel coadjuvante na fotografia moderna; o foco concentrava-se na capacidade do fotógrafo em dar significado a realidade, criando uma nova expressão à objetos e cenas cotidianas como as ruas e o dia a dia da população. Nasce com a fotografia moderna o conceito de "visão fotográfica" utilizado pela primeira vez no foto Clube Bandeirante ${ }^{44}$, onde foi incluído como categoria no concurso de fotografia. Após essa categoria ser criada, começa uma discussão sobre o olhar na fotografia, ou seja, a observação como ponto fundamental na concepção de uma fotografia.

ampliação da fotografia, além de muitas trocas sobre questões técnicas e de aperfeiçoamento da câmera e da fotografia.

${ }^{44} \mathrm{O}$ foto Clube Bandeirante foi criado em 1939, tornando-se na década de 1940 o maior clube fotográfico da cidade de São Paulo. Era o principal lugar de debate sobre as diversas formas estéticas da fotografia. Em 1942 promoveu o I Salão de Arte Fotográfica de São Paulo e dois anos mais tarde foi criado o departamento de cinema, alterando o nome do Clube para Foto Cine Clube Bandeirante. 
O livro "A Fotografia Moderna no Brasil”, escrito pela arquiteta e crítica de arte Helouise Costa e Renato Rodrigues da Silva, professor de arte na Universidade Federal Fluminense (UFF), discute o amplo movimento da fotografia moderna no Brasil e suas principais vertentes. O livro inicia apresentando a prática fotoclubista brasileira que irá culminar nas propostas feitas pelos fotógrafos que participaram do movimento moderno. Apesar da abrangência do título, o texto tem como foco os anos de 1930, 1940 e 1950, fazendo apenas uma referência no último capítulo sobre a permanência da proposta moderna na produção fotográfica da década de 1980.

Helouise Costa afirma que: "Por um lado a visão fotográfica moderna inventariava o cotidiano, ressemantizando-o; por outro, questionava a própria estrutura da linguagem fotográfica, o seu código e suas implicações. $" 45$

\subsection{A fotografia moderna no Brasil}

A fotografia moderna é um conceito amplo, que surgiu na primeira metade do século XX na Europa e nos Estados Unidos. Tem como base a projeção de uma cultura e uma sociedade industrializada, portanto, tem o nascimento dos grandes centros urbanos concomitante com o afastamento de movimento artísticos que até então estavam em voga.

É importante ressaltar que o Brasil foi apenas uma vertente desse movimento, que se inicia de forma tardia, apenas no início de 1930. Porém é importante ressaltar que a fotografia, a partir de 1840, já estava em circulação pelo Brasil, apesar do movimento se expandir em 1860 com as casas fotográficas e a disseminação das fotografias vernaculares por todas as camadas da sociedade brasileira. ${ }^{46}$

A expansão da fotografia e sua inserção no movimento modernista foi elaborada de formas diferentes. Na Europa não se teve nenhuma formação de um grupo específico, apesar disso, tiveram muitos fotógrafos que foram as bases das

\footnotetext{
${ }^{45}$ COSTA, Helouise \& SILVA, Renato Rodrigues da. A fotografia Moderna no Brasil. São Paulo: CosacNaify, 2004, p.82.

46 É importante ressaltar o pioneirismo de Hercule Romuald Florence que fez experimentos fotoquímicos para impressão em papéis sensibilizados com sais de prata e cloreto de ouro em 1933 e que daria ao Brasil o status da descoberta da fotografia, já que Daguerre só fez seus primeiros daguerriotipos em 1839, na França.
} 
inovações técnicas fotográficas, ampliando seus espectros para outras formas do uso da fotografia, como as colagens, os diferentes recortes e outros mecanismos que foram utilizados para trabalhar a imagem.

Dentre esses fotógrafos europeus os mais atuantes foram Man Ray, Alexandre Rodchenko, Réne Magritte, entre outros, exemplos de importantes fotógrafos modernos. Nos Estados Unidos o início da fotografia moderna esteve ligado à figura de Alfred Stieglitz, diretor das revistas trimestrais Câmera Work e Galeria 291. Essas duas revistas foram o ponto inicial para as primeiras experiências modernas. Os padrões pictorialista utilizados até então foram sendo trocados pela busca por uma fotografia direta com o mundo real, ou seja, algo que fosse contra as propostas que vigoravam até a época. Esse novo método de fotografia não exclui imediatamente o movimento pictorialista que ainda vigorava e permaneceu inalterado, tanto nos Estados Unidos quanto na Europa.

Esse movimento no Brasil acontece três décadas após seu início na Europa e nos Estados Unidos, mas isso não impede o movimento de inovar, não só com as técnicas, mas com um tipo de estética que se transformara em algo marcante na cultura brasileira.

A relevância da fotografia moderna no Brasil foi enorme, decorrendo se dela diversos debates e estudos acerca do tema. Outro aspecto importante foi a quantidade de fotógrafos existentes e as suas mais variadas linhas, que vai do fotojornalismo até a as mais abstratas e aqueles com foco apenas na arte. Podemos citar as figuras de José Medeiros (fotojornalista do Cruzeiro) e as experiências dos fotógrafos Farkas e Geraldo de Barros que misturam conceitos das artes plásticas com a fotografia. A historiadora Ana Maria Mauad explicita que a fotografia, nos anos do pós-guerra, torna-se fundamental para a arte brasileira. Segundo a autora:

"Ao longo desse período se consolidaram certas práticas, propriamente fotográficas, tais como o predomínio da fotorreportagem na imprensa ilustrada e mudanças estéticas no plano editorial das publicações, bem como o surgimento e a consolidação de uma atividade fotográfica associada à produção de uma documentação social de caráter visual. Além disso, assistiu-se à ampliação das trocas capitalistas no mercado da indústria cultural, a produção de notícias como mercadoria, o engajamento da 
imagem fotográfica e o registro dos movimentos sociais, a participação da fotografia no campo da arte experimental e suas relações com a cultura pop.."

\subsection{A fotografia como expressão do exílio}

A construção de museus, entre os mais significativos Museu de Arte de São Paulo - MASP (1947) e o Museu de Arte Moderna - MAM (1948) ${ }^{48}$, das diversas instituições, clubes e associações de artes criadas nas décadas de 1940 e 1950 eram reflexos da formação de um movimento moderno artístico no Brasil. Apesar do movimento ser diversificado em suas linhas e técnicas, o principal foco era a busca e a criação por algo que demonstrasse a cultura brasileira sem, necessariamente, ter que voltar ao passado, há no movimento moderno uma busca incessante pelo novo. Nessa busca a fotografia se encaixava perfeitamente, não só para Alice Brill, mas para tantos outros fotógrafos que vão demonstrar um novo olhar a situações do cotidiano pois não existia um vínculo forte ao passado e não havia uma busca por uma única identidade. Entre esses fotógrafos estão Hans Günter Flieg, Hildgard Rosenthall entre outros.

Hans Flieg em uma entrevista diz: "Eu vim como exilado, mas não me sinto nem um pouco exilado no Brasil. E, sem dúvida, o meu trabalho me ajudou a criar raízes. "49 Havia na arte um porto seguro, era lá no mundo, não tão concreto, que eles acreditavam que podiam fixar raízes.

Edward Said demonstra esse sentimento ao escrever: "Às vezes me sinto como um feixe de correntes que fluem. Prefiro isso à ideia de um eu sólido, à identidade a

\footnotetext{
${ }^{47}$ MAUAD, Ana Maria. O olhar engajado: fotografia contemporânea e as dimensões políticas da cultura visual. ArtCultura, Uberlândia, v. 10, n. 16, pp. 33-50, jan.-jun, 2008, p.34. http://www.artcultura.inhis.ufu.br/PDF16/A_Mauad.pdf. (visualizada no dia 03/03/2018).

${ }^{48}$ Os dois museus foram idealizados pelos empresários Assis Chateaubriand e Francisco Matarazzo Sobrinho. No MASP, sob a direção de Pietro Bardi, realizaram-se as primeiras exposições de fotografia no Brasil, que apresentaram as obras de Geraldo de Barros e ThomazFarkas.

PARADA, Maurício Barreto Alvarez. A fundação do Museu de Arte Moderna do Rio de Janeiro: a elite carioca e as imagens da modernidade no Brasil dos anos 50. Revista Brasileira de História , São Paulo, v. 27, pp.113-128, 1995.

${ }^{49}$ Entrevista feita em 4 de maio de 2008 pela DW-WORLD.DE: http://www.dw.com/pt/hans-g\%C3\%BCnter-flieg-o-fot\%C3\%B3grafo-da-modernidade-brasileira/a$\underline{3303265}$ (visualizada no dia 26/06/15).
} 
que tanta gente dá importância. [...] Com tantas dissonâncias em minha vida, de fato aprendi a preferir estar fora do lugar e não absolutamente certo ",50

Alice Brill expunha esse mesmo sentimento em uma carta quando ela descreve que: "A arte era tudo para mim: refúgio e esperança, o sonho de uma liberdade perdida precocemente diante da adversidade do destino. "51

A experiência de exílio transformava as concepções sobre o mundo Ocidental já que o contexto político, social e cultural do momento afetava diretamente a vida de pessoas que vivenciaram esse deslocamento. Ocorria um desprendimento profundo de suas origens (língua, profissão, cultura e fontes de subsistências). A observação sobre o mundo em que viviam se torna singular, pois se desconectava de referências culturais e políticas que até então eram concebidas de forma natural e que ganhavam características inéditas nos anos de 1940 e 1950.

No livro "La historia como campo de Batalla", do historiador italiano Enzo Traverso, os artigos feitos pelo autor tem como intuito os debates historiográficos em torno das violências do mundo contemporâneo. Nesse sentido, Enzo Traverso utiliza a história das ideias e a história dos conceitos como a teoria para discutir os artigos. $\mathrm{O}$ sétimo capítulo analisa a relação entre exílio e violência, através dos conceitos criados por Edward Said. Para discutir o exílio, Enzo Traverso explana:

\footnotetext{
"Si su condicón de miembros de una minoria estigmatizada, compuesta de excluídos y perseguidos, los exponia mucho más que a los "autóctonos" a los cambio del clima político, transformando los en blancos privilegiados de la xenofobia y de la represión política, suposición de extranjeros, de apátridas os desarraigados resultabaun observatório privilegiado de los cataclismos que afectaban al mundo (y su própria existencia)."
}

Era nessa estrutura que o exílio possibilitava a interação com novas formas de pensar, havia no deslocado um sentimento de vazio e solidão. Esse sentimento não estava caracterizado apenas com a perda do contato com as pessoas mais próximas do seu círculo, mas também por não ter nenhum laço com o passado. O deslocado vivia

\footnotetext{
${ }^{50}$ SAID, Edward. Fora do Lugar. São Paulo: Companhia das Letras, 2004, p.429.

${ }^{51}$ ALARCON, Daniela. Diário íntimo. A fotografia de Alice Brill. São Paulo, 2008, p.121.

${ }^{52}$ TRAVERSO, Enzo. La Historia como campo de Batalla - interpreter las violencias del siglo XX. Buenos Aires: Fondo de Cultura Económica, 2012. Pg. 237
} 
em uma experiência dual, no qual o aqui e o lá se misturavam tornando-se uma amálgama. Essa mistura não era apenas a geográfica, mas englobava a experiência política, social, cultural e o próprio mundo cotidiano. Segundo o crítico literário Edward Said:

"O exilado sabe que, num mundo secular e contingente, as pátrias são sempre provisórias, Fronteiras e barreiras, que nos fecham na segurança de um território familiar, também podem se tornar prisões e são, com frequência, defendidas para além da razão ou necessidade. $\mathrm{O}$ exilado atravessa fronteiras, rompe barreiras do pensamento e da experiência." 53

Essa experiência deixava claro que conceitos como território, nação e pátria estavam permanentemente em trânsito ao perceberem que esses conceitos não estavam mais ligados ao mundo que os circundavam. Ficava pouco clara a percepção de um dentro e fora, ou seja, o mundo imaginário era tão real quanto o mundo vivido. Essa transformação na compreensão de mundo ficava explícita na procura da literatura e da arte como forma de expressar seus sentimentos e como estruturavam novamente suas vidas.

Ao compreender essa experiência, ficava claro que a arte se transformava em local seguro, portanto a arte criava possibilidades de conviverem no mundo em que os rodeava e sobreviver a experiências passadas, nesses casos, a arte se torna uma segunda casa.

A fotografia era, portanto, um caminho seguido por muitos deslocados. Ela é fundamental, como Hans Flieg afirmava, para a adaptação às novas culturas e políticas existentes nos países que os receberam.

A fotografia inaugurava na arte uma discussão profunda sobre a veracidade de suas imagens, consideradas as mais miméticas das artes - que representa o real de forma exata. As discussões sobre o uso e a própria imagem fotográfica estavam sempre em metamorfose. A fotografia já nasceu em um tempo de transformações e era por si só moderna pois havia a junção da técnica (componentes químicos) e da máquina, dessa forma a construção de objetos artísticos possibilitava um intenso debate. A fotografia dá a possibilidade pela primeira vez do homem se ver como realmente ele é, já que o espelho reflete uma imagem invertida do nosso rosto.

\footnotetext{
${ }^{53}$ SAID, Edward. Fora do Lugar. São Paulo: Companhia das Letras, 2004, p.58.
} 


\subsection{O campo da fotografia no Brasil}

No século XX, a fotografia teve um papel fundamental devido a produção das imagens feitas durante as guerras e propagadas através das revistas e jornais, tornando-se essencial para noticiar os fatos ocorridos, hoje já discutidos por acadêmicos e intelectuais da fotografia, temas ligados a formação dessas imagens como foram recebidas e concebidas durante as guerras e os combates aos longos do século XX e XXI. No Brasil, as primeiras revistas com enfoque em fotografia, foram a Manchete e o Cruzeiro que estiveram em circulação no início dos anos de 1940 e possibilitaram o crescimento do fotojornalismo no Brasil.

O nascimento de revistas com enfoque em fotojornalismo e dos clubes fotográficos foram importantes para os debates ocorridos na formação de uma fotografia moderna e brasileira. O Foto Clube Bandeirante, como citado acima, foi um dos marcos do nascimento da fotografia moderna, ou seja, ele foi um dos precursores de uma nova discussão no campo da fotografia. O clube foi uma iniciativa de fotógrafos que tinham como intuito as discussões sobre temas ligados a fotografia, onde trocavam experiências e apresentavam as novidades no campo da fotografia, o que gerou, em 1942, o I Salão de Artes Fotográficas de São Paulo. Portanto, o Clube Bandeirante foi um importante marco na construção do movimento. Em conjunto com o clube, vários fotógrafos mantinham experiências similares de forma independentes. Segundo Helouise Costa:

"A construção de uma estética moderna na fotografia brasileira, se fez pelo somatório de inúmeras pesquisas individuais não explicitamente direcionadas e muitas vezes afastadas no tempo, mas que a longo prazo nos permite identificar a instalação de um "novo olhar", em uma ruptura clara com a prática acadêmica."54

A presença do Foto Clube Bandeirante foi importante para o nascimento da fotografia moderna, pois além de criarem uma revista e os salões, eles tiveram ligados

\footnotetext{
${ }^{54}$ COSTA, Helouise \& SILVA, Renato Rodrigues da. A fotografia Moderna no Brasil. São Paulo: CosacNaify, 2004, p.35.
} 
ao abandono da fotografia pictorialista. Com isso foi inovado não só os processos da fotografia, como também os espaços de atuação, saindo de um espaço técnico e buscando um experimentalismo. Dentre os integrantes do clube estavam Thomas Farkas que iniciou seus trabalhos no clube em 1945, utilizando o contraluz e as linhas para compor suas imagens - foi um dos grandes nomes da fotografia moderna.

Outro importante membro do clube foi Geraldo de Barros que ingressou no clube em 1949. Suas fotografias são marcadas por experiências, ora sobrepondo as fotografias, ora desenhando no próprio negativo, expandindo, portanto, as formas de se compreender a fotografia. Geraldo de Barros foi o responsável por montar o laboratório fotográfico do Museu de Arte de São Paulo (MASP) em 1950. Esse processo foi elaborado com o auxílio de Thomas Farkas e German Lorca, sendo que Alice Brill também esteva ligada ao MASP por ter trabalhado como fotógrafa no mesmo período.

Demonstrando a interação que Alice Brill possui com os fotógrafos da época, apesar de não estar ligada diretamente ao Foto Clube Bandeirante, percebe-se que as ideias discutidas no clube tiveram influencia em sua forma de fotografar. Outro momento de encontro entre Thomas Farkas e Alice Brill foi a revista Habitat, onde os dois trabalharam como fotógrafos. O Foto Clube Bandeirante, mais tarde, ficou conhecido como escola paulista, por revistas especializadas. Helouise Costa e Renato Silva, discutem essa denominação, segundo os autores:

"Hoje se percebe que a classificação realmente procede, na medida em que essa produção apresenta a sólida unidade e que, salvo as diferenciações individuais, podese apontar, desde então, características gerais definidoras do conjunto da produção dos fotógrafos paulistas." 55

O auge da fotografia moderna ocorreu no ano de 1950, com o aumento de fotógrafos que aderiram ao movimento em São Paulo, como também em outras

\footnotetext{
${ }^{55}$ COSTA, Helouise \& SILVA, Renato Rodrigues da. Op. cit., p.49.
} 
cidades brasileiras, por exemplo o Rio de Janeiro ${ }^{56}$. Neste trabalho o enfoque consiste na cidade de São Paulo, visando a compreensão do espaço em que Alice Brill viveu suas experiências como fotógrafa.

Em conjunto com a fotografia moderna havia espaço para outros tipos de abordagens, como fotógrafos que possuíam uma obra que englobava tanto o modernismo como o pictorialismo, caso do fotógrafo Gaspar Gasparian. Neste período houveram as primeiras exposições dedicadas somente a fotografia ${ }^{57}$, expostas no MAM e no MASP, além da variedade de revistas especializadas, que podem ser reflexos do crescimento da fotografia dentro dos ambientes artísticos. Segundo Helouise Costa:

"A Escola Paulista marcou o auge da fotografia moderna brasileira, tanto pela qualidade artística da produção efetivada, quanto pelo número de fotógrafos que participaram do movimento. Foi o momento em que a fotografia moderna atingiu um grau de liberdade sem precedentes, o que permitiu que ela se estendesse ainda ate meados dos anos 60 com uma pratica renovadora., 58

A observação começava a ter um espaço maior nessas discussão, principalmente dentro do Foto Clube Bandeirante. Essa observação pode ser desmembrada em três variantes: a antropológica (onde a foco da imagem está em retratar culturas, povos e costumes); outro ponto da observação é aquela com o enfoque nas relações culturais e políticas, onde o ato fotográfico existe para documentar ou demonstrar algo que está acontecendo na sociedade como manifestações, catástrofes e outros processos que englobem a dinâmica social como, por exemplo, a figura do fotojornalista e, por último, a observação que nasce da contemplação que narra através da fotografia sentimentos e experiências pessoais.

Esses três caminhos citados não são separados, eles se cruzam dependendo das circunstâncias e das intenções dos fotógrafos, pois o fotógrafo ao se aproximar do

\footnotetext{
${ }^{56} \mathrm{Um}$ dos fotógrafos mais importantes na fotografia moderna do Rio de Janeiro foi José Oiticica Filho, que compunha fotografias a partir de fragmentos de fotos, fazendo montagens sobre fundos negros. Seu intuito era dar mais dramaticidades às suas composições.

${ }^{57}$ Dentre as diversas exposições sobre fotografia estavam: Em 1950, Geraldo de Barros expos no MASP; German Lorca no MAM-SP em 1952, Ademar Manarini em 1954 expos no MAM-SP.

${ }^{58}$ COSTA, Helouise \& SILVA, Renato Rodrigues da. Op. cit., p.63.
} 
objeto fotográfico utiliza mais de uma categoria de observação para chegar ao resultado final. Essa última base da tríade da observação, a contemplação, é a mais importante para o trabalho de Alice Brill, pois une a experiência pessoal e a representação no mundo concreto, ou seja, trazendo para a realidade através de objetos que aqui são as fotografias, ela representa a sua percepção do mundo e das experiências que ela viveu.

\subsection{As fotografias de Alice Brill}

A fotografia esteve sempre presente na vida de Alice Brill. Ao acompanhar sua trajetória pessoal nota-se a importância das fotografias. Como citado no primeiro capítulo, ao percorrer os países de exílio, utiliza a câmera fotográfica que ela ganhou do pai para registrar imagens durante todo esse trajeto e, em um poema, cita que seriam as fotografias o presente que sua mãe iria ganhar, mostrando assim a importância que a fotografia passaria a ter em sua vida.

Outro ponto fundamental para o trabalho fotográfico de Alice Brill foi a participação no Grupo Santa Helena, grupo fundado por Francisco Rebolo e Mário Zanini, em 1933, no prédio Santa Helena. Em um primeiro momento eles possuíam ateliês separados, mas com a inserção de novos pintores, eles se uniram e iniciaram o Grupo Santa Helena. Esse grupo foi fundamental para a construção da vida artística de Alice Brill pois além dela participar das aulas de pintura do grupo, também fazia incursões em lugares do interior para pintar paisagens.

Além disso, Alice Brill elaborou sua dissertação feita em Filosofia na Universidade de São Paulo (USP) sobre Mario Zanini, em 1982, transformado em um livro, cujo o título é "Mario Zanini e seu tempo", publicado em 1984. No livro Alice Brill discute a influência do artista no Grupo Santa Helena e sua trajetória artística. Sobre o grupo, Alice Brill afirma:

“ No caso do grupo proletariado, o registro do cotidiano, em suas obras, tem o caráter de diário íntimo, em sua simplicidade. Filhos de imigrantes de primeira ou segunda geração (ou ainda nascido no estrangeiro, como é o caso de Volpi e Pennacchi), procuram documentar a própria vivência de uma maneira pessoal; numa visão, por 
assim dizer, introspectiva, ou seja: de dentro para fora. É o registro humilde, baseado em observação direta da vida do povo de sua nova pátria."

Alice Brill, mostra a possibilidade de compreender como a observação e a compreensão sobre cenas cotidianas eram importantes para a fotografia moderna no Brasil. Ela possui um acervo com mais de 14 mil negativos, que estão guardadas no acervo do Instituto Moreira Salles. Alice Brill possui fotografias dos mais diversos temas, entre eles, os mais importantes, são os seguintes conjuntos: as imagens feitas no Hospital Psiquiátrico do Juquery, em Franco da Rocha, no ano de 1950, em que ela fotografou os pacientes em aulas de arte, o ateliê e os próprios artistas com suas obras.

Outro conjunto conhecido da obra de Alice Brill são as fotografias de crianças, esse conjunto foi construído durante a década de 1950, em que ela fotografou os filhos de amigos e conhecidos feitos por encomenda; a singularidade desse conjunto está em como a artista fotografava as crianças, pois ela captava as crianças não em estúdios como era comum nos de 1950, mas sim em brincadeiras com os pais, na praia e praças conseguindo retratar as crianças em cenas típicas da infância.

Fotografias da cidade de São Paulo fazem parte de outro conjunto fundamental da sua carreira, realizadas entre 1950 a 1951, em que ela fotografa exaustivamente a cidade, desmembrando os lugares e trazendo novos olhares em cenas do mundo cotidiano. Um artigo que apresenta e discute o conjunto da cidade de São Paulo é o trabalho de Marina Rago, uma arquiteta formada pela USP que possui trabalhos vinculados a temas ligados a fotografia. Marina Rago escreve um artigo sobre Alice Brill e suas fotografias da cidade de São Paulo publicado para a Revista Topoi, que tem como intuito trabalhar temas ligados a imagem e suas reflexões sobre as representações e práticas no campo da história. Marina Rago produz esse artigo, que teve início no projeto da FAPESP, intitulado "São Paulo: os estrangeiros e a construção da cidade de São Paulo", cuja proposta era analisar as transformações culturais da cidade a partir das influências dos estrangeiros que residiam no país

\footnotetext{
${ }^{59}$ BRILL, Alice. Mário Zanini e seu tempo. São Paulo: Editora Perspectiva, 1984, p.49.
} 
como artistas, operários, artesãos e outras técnicas que possibilitaram uma construção singular da cultura neste momento.

Marina Rago, traça o trabalho de Alice Brill, através de dois aspectos relevantes que são a história pessoal de Alice Brill, que vem para o Brasil como refugiada da Segunda Guerra Mundial por ser judia, e também por ser uma das poucas mulheres que trabalham no meio artístico durantes os anos de 1950.

Em um segundo momento, Marina Rago apresenta a cidade de São Paulo, que é a conexão entra fotografia, Alice Brill e as representações do nascimento de uma nova cultura. Para ela, os anos de 1950 teve um grande valor estético e cultural para a fotografia, já que naquele período houve uma profusão de trabalhos fotográficos sobre a cidade de São Paulo. O motivo dessa enorme produção estava ligado ao aniversário dos 400 anos da cidade de São Paulo. Neste período, há também uma discussão sobre o sentido de moderno e como ele era aplicada nas artes e assim nasce uma nova estética.

Durante este período, Alice Brill faz um trabalho sobre a cidade de São Paulo, que foi encomendado por Lina e Pietro Bardi que, na época, eram editores da revista Habitat. O intuito do trabalho seria a formação de um livro sobre São Paulo com as fotografias de Alice Brill. Marina Rago, chama atenção sobre a forma singular que Alice Brill retratava a cidade: havia uma ruptura entre o discurso de uma cidade ligada ao novo e a tecnologia com as fotografias feitas pela artista, que demonstravam uma cidade com diversas facetas que nem sempre estavam de acordo com os discursos formados na época.

Outra questão importante neste conjunto de fotografias eram as relações que a própria artista mantinha com a cidade. Fica claro que algumas fotografias são de lugares que sempre estiveram na vida pessoal de Alice Brill, já que ela busca lugares no subúrbio para compor esse conjunto. Eram lugares frequentados por ela há décadas quando participava do Grupo Santa Helena onde haviam aulas de pintura e desenhos ao ar livre.

É importante ressaltar que existe uma ligação concreta entre as diversas fases da vida da fotógrafa que faz com que seu trabalho se torne único e distinto; sua forma 
de fotografar estava ligada à sua pintura e sua história de vida. Ela se aproxima do movimento moderno brasileiro mas nunca deixa de demonstrar a sua identidade.

Neste ponto é importante para Marina Rago ressaltar a trajetória pessoal de Alice Brill, apresentando aspectos fundamentais para a compreensão da obra da artista. Alice Brill teve influência dos pais que eram artistas, do Grupo Santa Helena que ela participou durante os anos de 1930 e, também, dos seus estudos nos Estados Unidos, onde ela aprendeu o oficio de fotografar. Segundo Marina Rago:

"O período de sua formação artística junto a este coletivo de artistas, sobretudo os do Grupo Santa Helena que conviveram mais intensamente em aulas ou sessões de modelo vivo, possivelmente influenciou seu olhar sobre a metrópole, as paisagens suburbanas, o trabalho e as personagens urbanas. Brill fotografa o cotidiano urbano no movimento das feiras livres, o camelô na Lapa, as bancas de jornal, o sapateiro, o menino engraxate, assim como as filas nos pontos de ônibus do vale do Anhangabaú." ${ }^{\circ 0}$

Marina Rago, apresenta um panorama sobre os fotógrafos que residiam no Brasil durante a década de 1950, em sua maioria formados por estrangeiros que tiveram papel fundamental para ampliar e desenvolver a fotografia no Brasil, portanto foram crucias para a modernização dos campos culturais do Brasil. A autora, começa a questionar como esses artistas tiveram influência sobre a construção de um ideal moderno e como o trabalho de Alice Brill pode ser compreendido.

Para Marina Rago, o importante é relacionar as fotografias que foram publicadas e as que foram naquele momento deixadas, o que, para autora, demonstra o interesse em certas formas políticas e estéticas de uma determinada época. Alice Brill possui um olhar moderno, mas sempre com a peculiaridade de trazer à tona $\mathrm{o}$ contraste marcante, que podem ser vistos no uso da luz, e na marcante diferença entre o preto e o branco que existe, e, também, nos processos como as fotografias feitas em São Paulo demonstram. Marina Rago argumenta sobre como identificar as fotografias de Alice Brill, para ela existe uma tensão entre fotografias de arquitetura mas onde os edifícios e as construções não são vistas em primeiro plano. Seria então uma fotografia da cidade ou de arquitetura, que Mariana Rago considera haver uma

\footnotetext{
${ }^{60}$ RAGO, Marina. São Paulo: os estrangeiros e a construção da cidade de São Paulo. Revista TOPOI, São Paulo, junho 2012, p.11.
} 
intenção ao trabalhar esses dois aspectos nunca deixando claro qual deles é o mais importante.

Mariana Rago, faz um mapeamento das fotografias e dos livros de fotosas que foram publicados em comemoração dos 400 anos de São Paulo, ressaltando que não houve uma fotografia feita por uma mulher. Segundo sua análise:

"As fotografias de arquitetura publicadas no período são quase exclusivamente produzidas por homens. Em relação às mulheres atuantes no Brasil, ainda que fotografem a cidade e também arquitetura, aparentemente não estabelecem o vincula reconhecido entre alguns fotógrafos e arquitetos que se associam na divulgação do trabalho."

Ao pesquisar os fotógrafos que participaram das comemorações fica claro que a maioria estava ligada às revistas de arquitetura existentes na época como a Habitat, Acrópole, Módulo Arquitetura e Artes Visuais no Brasil. Alice Brill era na época uma das principais fotógrafas da revista Habitat, porém não conseguiu publicar nenhuma foto que estava no circuito de comemoração dos 400 anos de São Paulo.

Mariana Rago, chama atenção para o fato de que seu colega de trabalho Peter Schier publica um livro para o evento, onde apresenta fotografias com o mesmo estilo de Alice Brill. Ao longo do artigo a autora expõe a escassez de mulheres atuantes no campo da fotografia no Brasil, número que só cresce a partir dos anos de 1970.

Há também as imagens que retratam diversos artistas em seu ambiente de trabalho, entre esses artistas estão: Mario Cravo, Burle Marx, Victor Brecheret, Francisco Rebelo Gonsales entre tantos outros que faziam parte do seu círculo de amizade. Esse conjunto apresenta os diversos campos da arte nos anos de 1950 e como esses artistas se relacionavam com a produção de suas obras.

É importante ressaltar a discussão da verdade no campo da fotografia, pois a imagem é apenas um fragmento singular realizado pelo fotógrafo sobre o objeto que será fotografado. A verdade, portanto, para a fotografia depende de quem a interpreta

61 RAGO, Marina. Op. cit., p.15. 
e de quem fotografa. Não há uma intenção em compreender as fotografias como a voz da realidade, pois elas são fragmentos soltos sobre um dado momento.

A partir das fotografias de Alice Brill, é possível analisar como seu olhar é singular, por retratar a cidade e apresentar certas dualidades existentes nos grandes centros urbanos. A sensação de instabilidade presente em suas fotografias, são reflexos de sua própria experiência, motivadas por uma inconstância sobre a realidade em que vivia.

A geometria presente em suas imagens não são apenas escolhas estéticas, elas estavam relacionadas ao movimento modernista dos anos de 1950, do qual Alice Brill fazia parte. Esse movimento modernista no Brasil, eclodiu nos foto clubes onde eram debatidos temas ligados a uma nova construção de uma identidade brasileira, portanto, nesse momento havia uma nova forma de compreender a fotografia rompendo com o movimento pictorialista. Novas interpretações sobre a vida cotidiana existiam - o foco principal desses artistas estavam em retratar cenas corriqueiras do dia a dia, dando novos significados a realidade. 


\section{4- $O$ Juquery e as fotografias de Alice Brill}

O conjunto fotográfico do Hospital Psiquiátrico do Juquery feito por Alice Brill em 1950, é uma parte importante do seu acervo. Neste trabalho irei analisar essas fotografias com o intuito de unir as discussões que estão descritas nos capítulos anteriores. Dessa forma, o conjunto sobre o Juquery trará uma compreensão sobre o olhar e a forma como Alice Brill pratica a fotografia.

A escolha de Alice Brill para compor suas fotografias e os temas que ela opta para construir o seu trabalho será tratado aqui como resposta a essa transição que ocorreu em sua vida devido ao exílio imposto a ela. Portanto, este capítulo tem como intenção relacionar a trajetória pessoal da fotógrafa Alice Brill com seu trabalho artístico buscando demonstrar como exílio transforma o olhar da fotógrafa.

Alice Brill, em 1950, ao fotografar o Hospital Psiquiátrico do Juquery, tinha como objetivo principal registrar a sala de artes do hospital, conhecida como Ateliê Livre de Artes, local onde encontravam-se internos que utilizavam esse espaço como forma de tratamento. Esse conjunto fotográfico foi realizado a convite da artista e amiga de Alice Brill, Maria Leontina Franco ${ }^{62}$, que era colaboradora do projeto no Hospital do Juquery.

Leontina Franco era artista plástica e se envolveu no projeto para ajudar os pacientes a construir seus trabalhos artísticos. Alice Brill conheceu Maria Leontina Franco através do Grupo Santa Helena. As fotografias foram realizadas com a permissão do médico psiquiatra Mario Yhan e pelo diretor do hospital o médico Osorio César, que foram responsáveis pela implementação do ateliê no hospital. Segundo Lena Schufler, foi inserido neste momento novos tipos de terapia. Nas palavras da autora:

"Osório César, who had introduced this new type of therapy for schizophrenic patients at his clinic in São Paolo, soon became the key figure of this movement.

\footnotetext{
62 Maria Leontina Franco (1917-1984), pintora, gravadora e desenhista, foi uma artista ligada ao movimento moderno. Em 1940 inicia sua trajetória artística estudando no ateliê do pintor Antonio Covello. Em 1948 forma-se em museologia e 1950 inicia seu trabalho no Ateliê de Artes do Juquery.
} 
César had looked for alternative, less violent, forms of treatment and had begun using creative activities as part of his patient's therapy plan, which ultimately led to the establishment of an art studio on hospital ground: the Escola Livre de Artes Plásticas (abbr. ELAP) was born. Right from the beginning, he focused on an interdisciplinary exchange between art produced at the clinic and the contemporary art scene in São Paolo."63

O conjunto fotográfico foi elaborado ao longo de três dias. Alice Brill teve acesso irrestrito ao hospital, porém suas fotografias demonstram apenas três momentos distintos: o pátio externo, onde os internos ficavam ao livre, a ala das crianças e o ateliê. No ateliê ela produziu imagens do internos com seus trabalhos (fica clara a aproximação do estilo fotográfico que marca também outro conjunto importante de Alice Brill, que são os retratos feitos por ela de artistas plásticos como Mario Cravo, Rebolo, entre outros), fotografias do ambiente e por último fotografias das obras produzidas no ateliê. Somam um total de 40 fotografias, das quais 11 retratam os trabalhos plásticos elaborados no ateliê e 29 são fotografias dos artistas e do convívio no ateliê. Dentre o conjunto de fotografias, 16 estão anexadas neste capítulo e serão apresentadas e discutidas ao longo do texto. Essas fotografias estão sob guarda do Instituto Moreira Salles, existindo, também, 30 fotografias do mesmo conjunto no Museu de Arte Contemporânea de São Paulo.

Deste conjunto foi realizada a exposição "Arte e inconsciente: três visões do Juquery", onde foram apresentadas 11 fotografias de Alice Brill. Essa exposição foi criada pelo Instituto Moreira Salles e pela Secretária de Saúde do Estado de São Paulo, em 2002. A exposição reuniu as fotografias de Alice Brill, os desenhos de Lasar Segall e as obras dos artistas residentes no Hospital do Juquery. Essas obras foram cedidas pelo Museu Osório César e foram realizadas durante o ano de 1950, mesma data que foram feitas as fotografias de Alice Brill. O primeiro local que sediou a exposição foi o Instituto Moreira Sales de São Paulo (IMS-SP), entre 28 de agosto a 18 de dezembro de 2002. No mesmo período esteve exposta na Galeria IMS - Unibanco Arteplex, de 30 de agosto a 19 de novembro de 2002. Entre 7 de agosto a

\footnotetext{
${ }^{63}$ SCHUFLER, Lena. Photograpy from the Psyche: Alice Brill in the clinic of Juqueri, São Paulo 1950. Berlim, 2017, p.2.
} 
5 de outubro de 2003 a mostra esteve em exibição no IMS-MG e o último lugar onde foi apresentada a exposição foi no IMS-RJ, entre 11 de novembro de 2003 a 29 de fevereiro de 2004.

Existem dois trabalhos acadêmicos que discutem esse conjunto fotográfico, o primeiro é a tese de Tatiana Gonçalves, sob o título "A representação do louco e da loucura nas imagens de quatro fotógrafos brasileiros no século XX: Alice Brill, Leonid Streliaev, Cláudio Edinger, Claudia Martins". Nesta tese, publicada em 2010, pela Universidade Estadual de Campinas, a autora faz um mapeamento das iconografias realizadas sobre temas que circundavam a loucura. Na primeira parte do texto, ela discute as primeiras imagens que representavam a loucura e como isso foi utilizado para estudos na psiquiatria; na segunda parte ela começa a discutir a fotografia e os fotógrafos que realizaram ensaios nos hospitais psiquiátricos no Brasil.

O segundo trabalho é um artigo escrito pela historiadora alemã Lena Schäffler, "Photograpy from the Psyche: Alice Brill in the clinic of Juqueri, São Paulo $1950^{״ 64}$, neste artigo ela apresenta a trajetória da fotógrafa e analisa as imagens que Alice Brill produziu no Hospital do Juquery. Este trabalho faz parte da tese escrita por Schäffler, cujo o título é, "Das dynamische Verhältnis von Kunst und Psychiatrie in Brasilien zwischen 1920 und 1980," da Freie Universität Berlin. ${ }^{65}$

Esses trabalhos demonstram a importância dessas fotografias, dos desdobramentos de estudo que elas possuem, porém, ainda pouco exploradas no Brasil.

\subsection{O hospital}

O Hospital Psiquiátrico do Juquery, foi criado em 1895, cujo objetivo era desobstruir os hospitais psiquiátricos da cidade de São Paulo, que neste caso, eram o

\footnotetext{
${ }^{64}$ Schufler desenvolveu esse artigo a partir de sua tese sobre os ateliês de artes nos hospitais de psiquiatria no Brasil. Esse artigo foi escrito para ser apresentado no primeiro Congresso sobre fotógrafas mulheres no MAC, em agosto de 2017.

${ }^{65}$ Schäffler, Lena: Das dynamische Verhältnis von Kunst und Psychiatrie in Brasilien zwischen 1920 und 1980, unv. Diss., Freie Universität Berlin 2018.
} 
Hospital da rua São João e a Chácara da Ladeira do Tabatinguera. Outra intenção que havia naquele período para a construção do Hospital do Juquery era a criação de colônias agrícolas onde os internos exercessem trabalhos que os ajudariam na recuperação e na reintegração a sociedade. Havia também hospitais em determinadas cidades brasileiras com o mesmo modelo, entre eles se encontravam o Hospício de Alienados no Rio de Janeiro, que em 1902 criou colônias agrícolas que possuíam o mesmo intuito citado acima, sob a direção de Juliano Moreira.

O Hospital do Juquery inicialmente era um local apenas para adultos mas, em 1922, foi inaugurado uma pavilhão infantil, chegando a ter em 1950, 3520 crianças, ano das fotografias de Alice Brill. Este pavilhão era chamado pavilhão escola, mais tarde se tornaria a escola Felix Pacheco. Em 1950, o Hospital do Juquery possuía uma população de cerca de 15 mil internos, divididos em pavilhões femininos, masculino e infantil. O espaço destinado ao ateliê foi concebido em 1943 como consequência de estudos vinculados a tratamentos terapêuticos com auxílio de artes e funcionou até a década de 1970 quando foi fechado. Em um primeiro momento havia apenas uma sala de pintura no ateliê, seis anos mais tarde iriam inaugurar o ateliê que foi fotografado por Alice Brill. A criação do espaço foi concebida sob o comando do médico psiquiatra Osório César ${ }^{66}$, que era então diretor do Hospital do Juquery, segundo Tatiana Gonçalves:

“A forma pela qual se deu o desenvolvimento, o pensamento e utilização de recursos expressivos derivou do fato do Juquery ter estado sob a responsabilidade de Osório César (esteve envolvido com esta instituição de 1923 a 1965 no Juquery) médico psiquiatra que se interessava por questões pertinentes ‘as relações entre expressividade, criatividade e loucura. Sua presença e atuação foram fatores para ali se constituir uma reflexão que possibilitou a realização dos trabalhos com os internos.",67

${ }^{66}$ Osorio Cesar (1895-1979), nasceu na Paraíba, em uma família de músicos, violinista, foi professor
de violino para poder se manter enquanto estudava odontologia. Cursou medicina, após terminar a
faculdade de odontologia e começou seu trabalho no Juquery em 1925. Defendia a livre expressão
artística como tratamento para o requilíbrio de emoções em pacientes com distúrbios psíquicos.
${ }^{67}$ GONÇALVES, Tatiana Fecchio da Cunha. A representação do louco e da loucura nas imagens
de quatro fotógrafos brasileiros do século XX: Alice Brill, Leonid Streliaev, Cláudio Edinger, 
As fotografias relacionadas ao tema da psiquiatria começaram a ser produzidas na metade do século XIX, sendo, inicialmente, utilizadas como instrumentos científicos. O primeiro médico que trabalhou com imagens para análise dos seus pacientes foi o Dr. Hugh Diamond, membro fundador da Royal Photographic Society, na Inglaterra, logo em seguida tiveram registros na França e nos Estados Unidos. Tatiana Gonçalves apresenta sua pesquisa sobre o início da fotografia nos hospitais psiquiátricos, segundo a autora:

"A aplicação da fotografia no campo da medicina, em especial no campo da psiquiatria, teve seu início no século XIX na França e Inglaterra. Estas primeiras imagens geraram uma maneira de representar o "louco" e a loucura que se perpetuou de maneira decisiva na descrição da loucura no século XX. Por um lado a fotografia psiquiátrica se relacionou com uma tradição de representação do "louco" e da loucura já existentes na qual eram priorizadas a questão da fisionomia. Por outro lado estas fotografias corresponderam a um desejo científico de verdade, propiciada pelo aparato mecânico que atrelou esta produção à ideia do indicial.",68

No Brasil o uso da fotografia também foi feita com mesmo intuito, o de registro de doenças. No início do século $\mathrm{XX}$, começaram os registros através de cadastros que continham uma fotografia em formato $3 \times 4$ visando a identificação do paciente. Há também imagens realizadas para descrever síndromes, crises e demonstrar procedimentos médicos, portanto, as fotografias tinham como intuito único o registro de internos e a catalogação de doenças, ou seja, objetivo enciclopédico. ${ }^{69}$

As primeiras imagens realizadas no ateliê de artes do Juquery foram as fotografias de Brill. Ela foi pioneira no Brasil em realizar imagens que não tinham

Claudia Martins. Tese (doutorado) Instituto de Artes, Universidade Estadual de Campinas, São Paulo, 2010, p. 155.

68 GONÇALVES, Tatiana Fecchio da Cunha. Op. cit., p.74.

${ }^{69}$ Outras informações sobre a discussão ver na tese de GONÇALVES, Tatiana Fecchio da Cunha. A representação do louco e da loucura nas imagens de quatro fotógrafos brasileiros do século XX: Alice Brill, Leonid Streliaev, Cláudio Edinger, Claudia Martins. Tese (doutorado) Instituto de Artes, Universidade Estadual de Campinas, São Paulo, 2010. 
como intuito o registro de doenças e pacientes. Suas imagens apresentam o dia a dia dos internos no ateliê, suas obras e retratos dos artistas.

\subsection{A relação entre o Ateliê de Arte e as fotografias de Alice Brill}

Ao observar o conjunto de fotografias feitas por Alice Brill, nota-se que a fotógrafa percorre os corredores, o pátio e o ateliê; esse trajeto foi fotografado e demonstra de uma forma geral como viviam os internos. Suas primeiras imagens referem-se ao lado externo do hospital, são poucas fotografias e nelas aparecem os internos no pátio. Ao olhar as fotografias desse espaço é possível descrever como era um local confuso, pois há muitos internos ocupando um espaço relativamente pequeno. Existe uma dispersão entre os internos, nenhum deles olha para câmera, neste momento Alice Brill observa de longe e fotografa o ambiente como um todo. Além da distância que foram feitas as fotografias, há um muro e uma grade que separam e segregam os internos demonstrando que eles não estão apenas separados no hospital mas também da sociedade, portanto, eles não possuem um lugar. Tatiana Gonçalves analisa essa forma de encarceramento em suas palavras:

“Já no século XVII, a grade como descrição do cativo, enjaulado, perigoso, aparecem em diversas composições que representam o "louco" no espaço de internação dos hospitais psiquiátricos. Assim como as prisões tem barras de ferro, o espaço manicomial é protegido por grades que nos permite observar o interno e ele também observa o que está fora, longe do seu alcance. É uma interface de relação que permite a observação, mas não permite o acesso, que restringe um interno a um espaço definido, sem circulação." ${ }^{, 70}$

Os internos usam uniformes iguais como se pode analisar dando uma sensação de falta de identidade, não havia uma individualidade. Ao contrário do resto do trabalho onde os artistas/internos, demonstram suas obras de arte, eles aparecem em primeiro plano, esses retratos são iguais aos que Alice Brill fez em outro conjunto

\footnotetext{
${ }^{70}$ GONÇALVES, Tatiana Fecchio da Cunha. Op. cit., p.175.
} 
muito importante de artistas consagrados. No restante das fotografias feitas no Hospital do Juquery observa-se também a movimentação da fotógrafa pelo espaço. Alice Brill percorre a sala fotografando de diversos ângulos, registrando os trabalhos, fazendo retratos individuais e da sala com os artistas trabalhando.

Podemos pensar nesses artistas como exilados, eles estão a margem de uma sociedade, que de certa forma nega um lugar a eles. O uniforme e o local onde se encontram são dois fatores que explicitam as condições de não pertencimento. Quando em contato com a arte, fica claro uma outra forma de posicionamento que se percebe ao serem fotografados. A obra, parte integrante da personalidade do artista, confere aos internos uma identidade; elas se transformam no caminho para a busca de inserção no mundo. A loucura vista como um "não lugar", onde não existe uma ordem no campo social, portanto, há um trânsito liberado de ideias e expressões. A arte se torna um campo seguro, onde eles expõem um mundo que ultrapassa a realidade vivida no hospital.

Essas fotografias foram apresentadas em dois momentos, na revista Habitat, onde Alice Brill trabalhou como fotógrafa. As primeiras fotografias fizeram parte do artigo escrito por Mario Yahn, em 1951, intitulado "Pintores sem saber"71 e o segundo artigo de José Geraldo Vieira, em 1956, denominado "Arte ingênua",72 que também possuía fotografias de Alice Brill. Os dois artigos discutem a inserção dos ateliês de artes em hospitais psiquiátricos e os benefícios para o bem-estar dos pacientes. As fotografias de Alice Brill eram utilizadas para expor os trabalhos feitos pelos pacientes e as diferentes formas que eles utilizavam para expressar sua arte. Este trabalho, portanto, pode ser compreendido como sendo foto jornalístico e, também, um trabalho artístico.

Tatiana Gonçalves apresenta em sua tese, uma entrevista feita com o marido de Alice Brill, Juljan Czapski, onde ele narra os três dias em que a artista esteve no hospital. Durante a entrevista ele descreve que havia sim um interesse pessoal de Alice Brill e que não seria algo apenas jornalístico. Segundo J. Czaspki, Alice Brill “[...] achava interessante como o pessoal desenhava e como pintava, os trabalhos em

\footnotetext{
71 YAHN, Mario. Pintores sem saber. In: Habitat. Arquitetura e Artes no Brasil, Vol. 2,.1951.

${ }^{72}$ VIERA, José Gerald. A arte ingênua. In: Habitat. Arquitetura e Artes no Brasil, Vol. 35. 1956.
} 
exposição nas paredes do Ateliê. Alguns dos doentes chegavam e explicavam os quadros. Estas coisas ela achava interessante [...]" em outro momento da entrevista ele novamente fala dos interesses de Brill ao realizar o trabalho "[...] fotos foram feitas como curiosidade, a Alice achou curioso - tem mais umas duas ou três daquele pessoal que ficava catatônico numa posição qualquer estranha durante horas, então ela achou isto curioso e fotografou"73.

Ao analisar as fotografias feitas no hospital fica claro que a intenção de Alice Brill era fotografar o ambiente do ateliê e a produção que ocorria ali dentro. Esse interesse pode ser compreendido através da trajetória da fotógrafa que também era pintora e que possuía uma curiosidade sobre as diversas técnicas de arte, como por exemplo, o batik, que pode ser observado em suas telas.

As fotografias sobre o ateliê do Hospital Psiquiátrico do Juquery estão no MAC sendo que três dessas imagens encontram-se com legendas escritas a lápis por Alice Brill. Uma das imagens apresenta apenas o nome do artista que pintou a obra fotografada por Alice Brill. As outras duas fotografias descrevem o nome do artista e outras considerações que ela observou durante os três dias em que esteve no Hospital. Isso comprova que havia entre a fotógrafa e os artistas/internos uma interação. Fica nítido nessas legendas a preocupação de Alice Brill com a vida pessoal e a intenção do artista ao pintar os quadros.

A primeira fotografia, que possui legenda, é a imagem em que aparece o quadro com a pintura de um leão (imagem 14). Nessa fotografia, Alice Brill descreve no verso: "Haydeé tem 23 anos, internada a 10 anos. Vida trágica e acidentada antes disto. Esquizofrênica, consciente, mas as vezes irritada e agitada. Desejaria aprender inglês e tocar harpa. Um leão, que parece ruindo, porém, sua intenção foi fazer o leão mostrando os dentes. Ha outros bichos." Esse quadro foi pintado por Haydeé, segundo Alice Brill, a artista também é fotografada em outro momento onde ela aparece com todas as suas obras ao fundo (imagem 4).

\footnotetext{
73 Entrevista concedida a Tatiana Gonçalves, para leitura completa ver: GONÇALVES, Tatiana Fecchio da Cunha. A representação do louco e da loucura nas imagens de quatro fotógrafos brasileiros do século XX: Alice Brill, Leonid Streliaev, Cláudio Edinger, Claudia Martins. Tese (doutorado) Instituto de Artes, Universidade Estadual de Campinas, São Paulo, 2010.
} 
Em outra fotografia de Alice Brill, em que ela retrata o quadro de um artista (imagem 16), há uma descrição com o nome do artista, anos que estava no hospital e sua relação com os quadros que pinta. Descrição da artista: "Teofilo - internado há 11 anos esquizofrênico. Desorientado no tempo e no meio, não sabe a quanto tempo está internado nem porque. Só faz esse tipo de desenho, representando as mais diversas fachadas de casa. "74

O conjunto fotográfico do ateliê de artes do Juquery possui uma dupla importância: histórica por se tratar das primeiras fotografias que registram o ambiente artístico do hospital, que era um projeto inovador nos hospitais brasileiros, e também por seu valor artístico apresentando um olhar único e buscando compreender a relação dos artistas com suas obras.

\subsection{As fotografias de Alice Brill no Hospital Psiquiátrico do Juquery}

É importante ressaltar a discussão da verdade no campo da fotografia pois a imagem é apenas um fragmento singular realizado pelo fotógrafo sobre o objeto que será fotografado. A verdade, portanto, para a fotografia depende de quem a interpreta e de quem fotografa, não há uma intenção em compreender as fotografias como a voz da realidade, pois elas são fragmentos soltos sobre um dado momento. Como deixa claro a crítica de arte e escritora Susan Sontag, em seu livro "Sobre a Fotografia" em que ela discute as relações da fotografia com a arte e a relação de conflito em que a fotografia se encontra. Para Susan Sontag:

"A contingência das fotos confirma que tudo é perecível; a arbitrariedade da evidência fotográfica indica que a realidade é fundamentalmente inclassificável. A realidade é resumida em uma série de fragmentos fortuitos - um modo infinitamente sedutor e dolorosamente redutor de lidar com o mundo. ",75

\footnotetext{
${ }^{74}$ Essas legendas foram encontradas na análise das fotografias que estão no MAC - Museu de Arte Contemporânea de São Paulo.

${ }^{75}$ SONTAG, Susan. Sobre a Fotografia. São Paulo: Companhia das letras, 2004, p.95.
} 
Sontag, ao discutir sobre a verdade na fotografia e desconstruir a imagem como apenas o registro de um momento, faz uma conexão com o estilo de fotografia de Alice Brill e do grupo de fotógrafos da década de 1950 que abandonaram o estilo pictorialista e buscaram novas concepções para a construção da imagem. Apesar de tardiamente esse movimento que questiona a forma pictorialista de fotografar foi denominado como uma fotografia moderna, pois questiona a verdade e também traz um registro fragmentado que não corrobora uma verdade única, apresentado uma "cascata" de compreensões sobre o mundo.

Sabendo da limitação da transformação da imagem em texto e considerando a discussão de Susan Sontag sobre a diversas realidades de uma única imagem,infatizo alguns pontos como exercício de pensamento sobre esse conjunto fotográfico. $\mathrm{O}$ universo do estranho esteve presente em todos os conjuntos de fotografia de Alice Brill, isso traduz a sua compreensão sobre o mundo a sua volta e pode ser considerado uma resposta aos diversos deslocamentos de sua vida. Ao observar as imagens concebidas por Alice Brill formam uma nova concepção sobre o louco, pois ela não fotografa a instabilidade do local, ela faz um contra ponto com as imagens que até então eram apresentadas, fugindo do vocabulário imagético que era realizado naquele momento. Nas imagens a seguir, os pacientes estão serenos, alguns trabalham no ateliê, outros aparecem lendo ou comendo. Essas fotografias demonstram o cotidiano do ateliê e enfatizam um local calmo não de desespero. Portanto, a sanidade neste conjunto aparece através da arte, do ambiente do ateliê, desta forma a fotografa faz um caminho que liga a arte como forma de expressão e também como tratamento terapêutico. Em todas as fotografias percebe se uma melancolia, principalmente nos retratos feitos pela fotografa, nesse ambiente fica expressa a ambiguidade dos olhares perdidos mas ao mesmo tempo expressa um reencontro com uma identidade que pode ser apresentada através da arte.

Como dito acima, as fotografias apresentadas neste trabalho não têm a intenção de mostrar a realidade ou a verdade sobre aquele momento, apesar de todo o contexto que foi formado durante esse capítulo. O ponto principal é compreender o olhar de Alice Brill ao retratar o ambiente e a movimentação dos artistas, neste conjunto é muito mais forte a sua conexão com o tema do que necessariamente o 
catalogação dessas imagens. Ao expor uma parte dessas fotografias, o intuito é apresentar esteticamente essa construção e também fazer a conexão entre imagem e texto, algo complexo, pois é muito difícil dar palavras às imagens. Como diria a pintora Carmen Herrera, em seu documentário "The 100 years show", produzido por Alison Klayman, ao ser questionada sobre seu trabalho ela responde: "se eu pudesse colocar essas coisas (seu trabalho artístico) em palavras, eu não estaria pintando "76. Portanto, as imagens de Alice Brill expressam muito mais esteticamente do que qualquer escrita sobre elas.

${ }^{76}$ KLAYMAN, Alison. The 100 years show. EUA, 2015. 


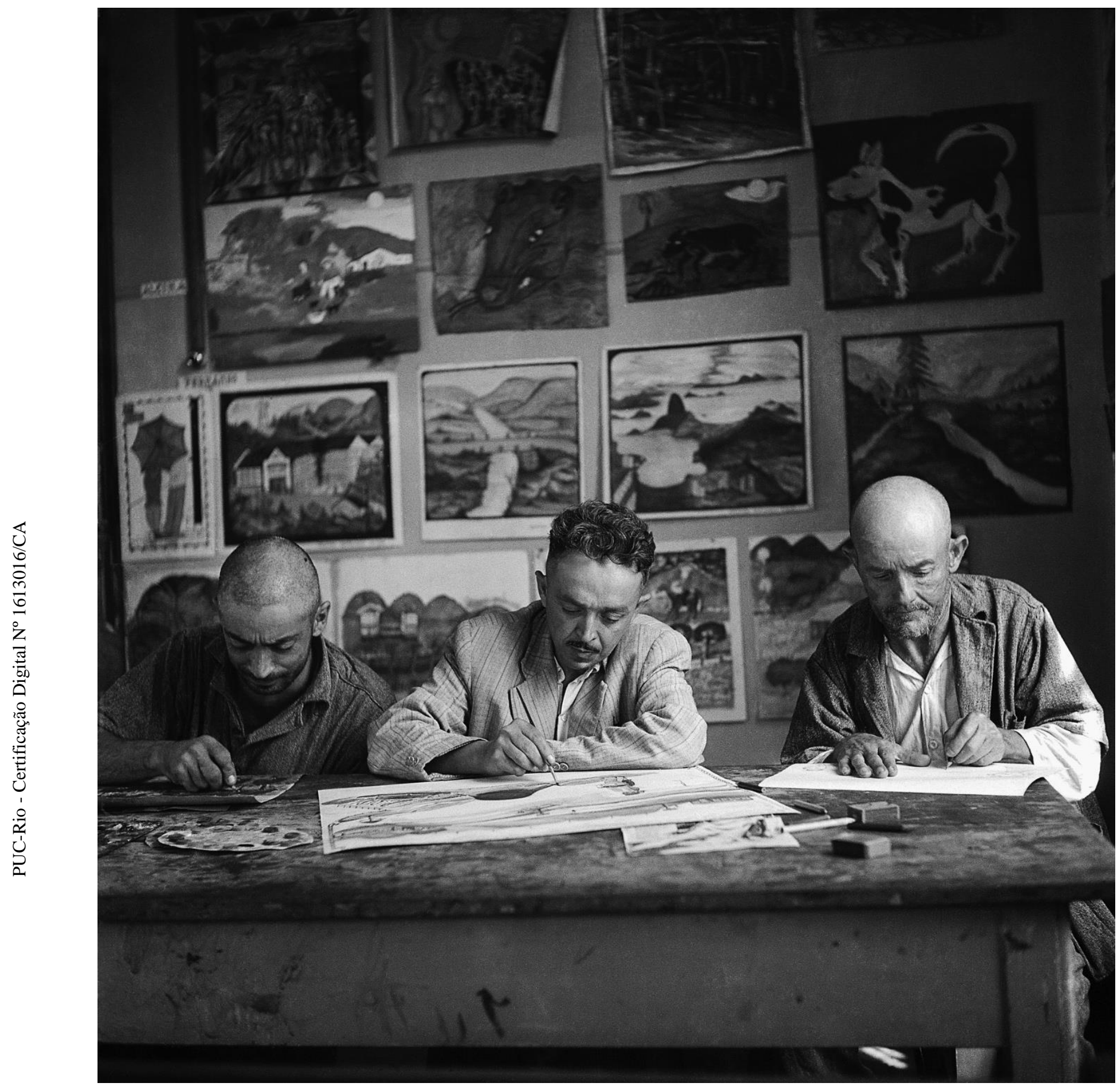

Brill, Alice. Fotografia sem título, 1950 ( Instituto Moreira Salles). 


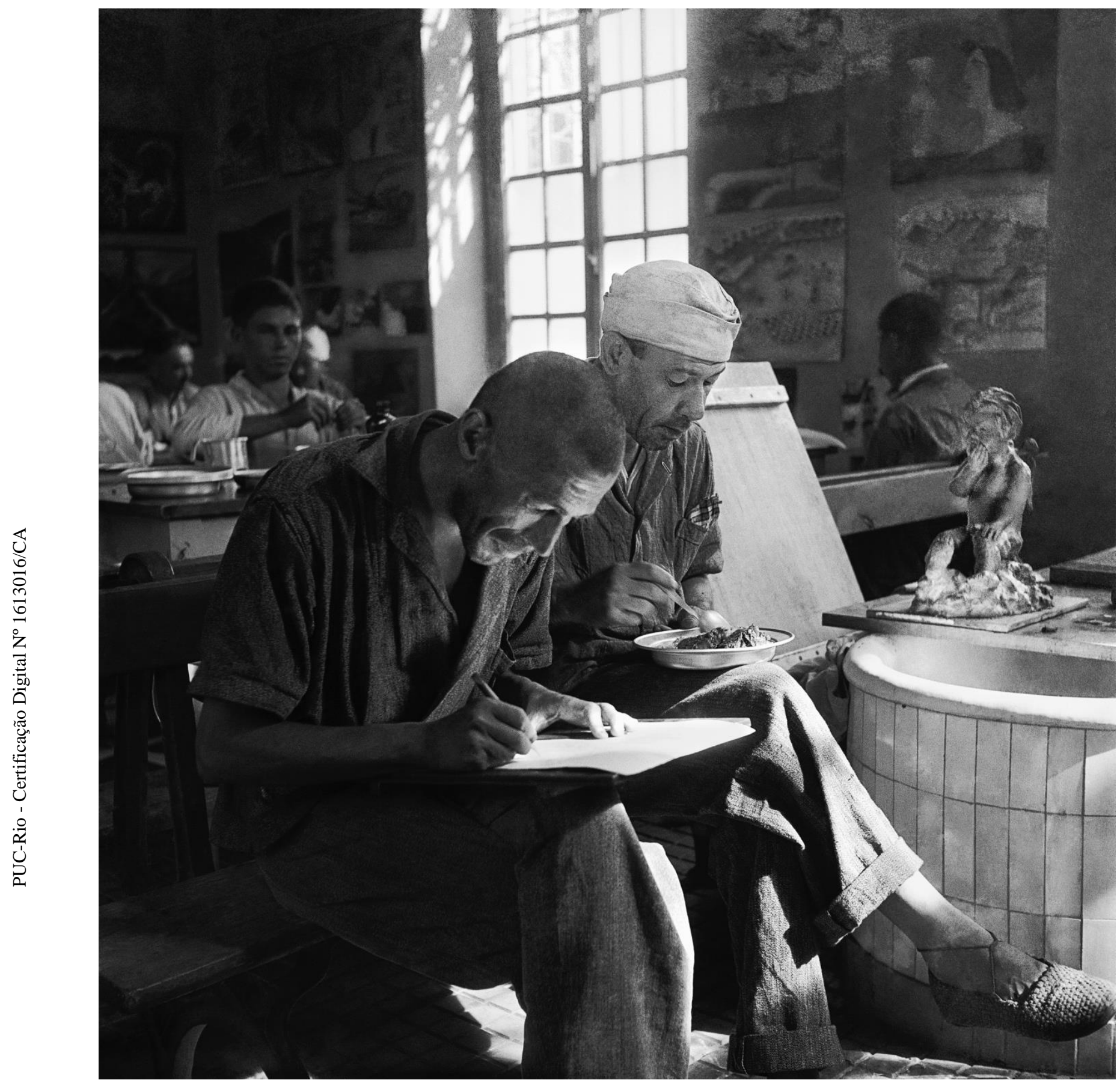

Brill, Alice. Fotografia sem título, 1950 (Instituto Moreira Salles). 


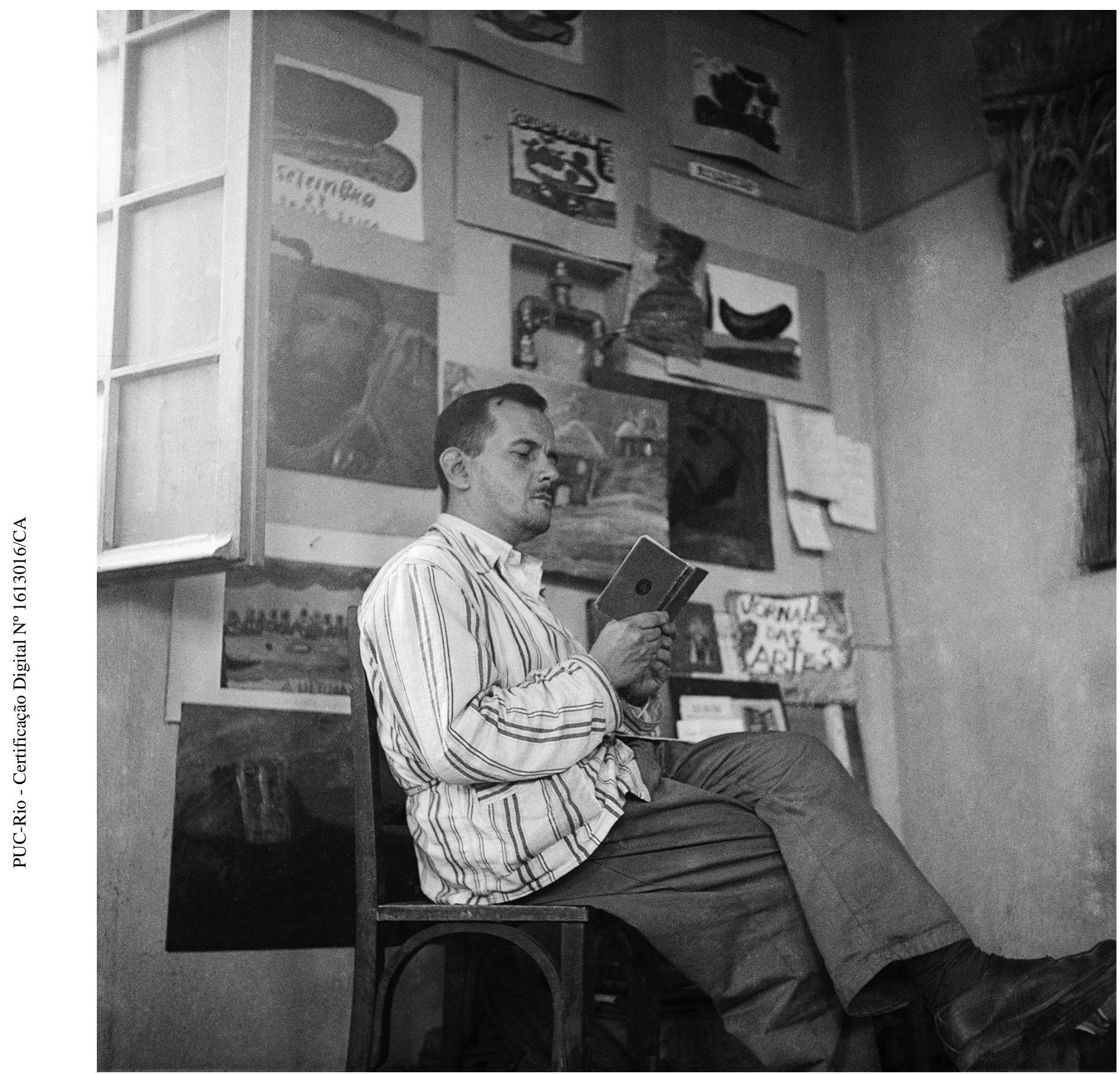

Brill, Alice. Fotografia sem título, 1950 ( Instituto Moreira Salles). 


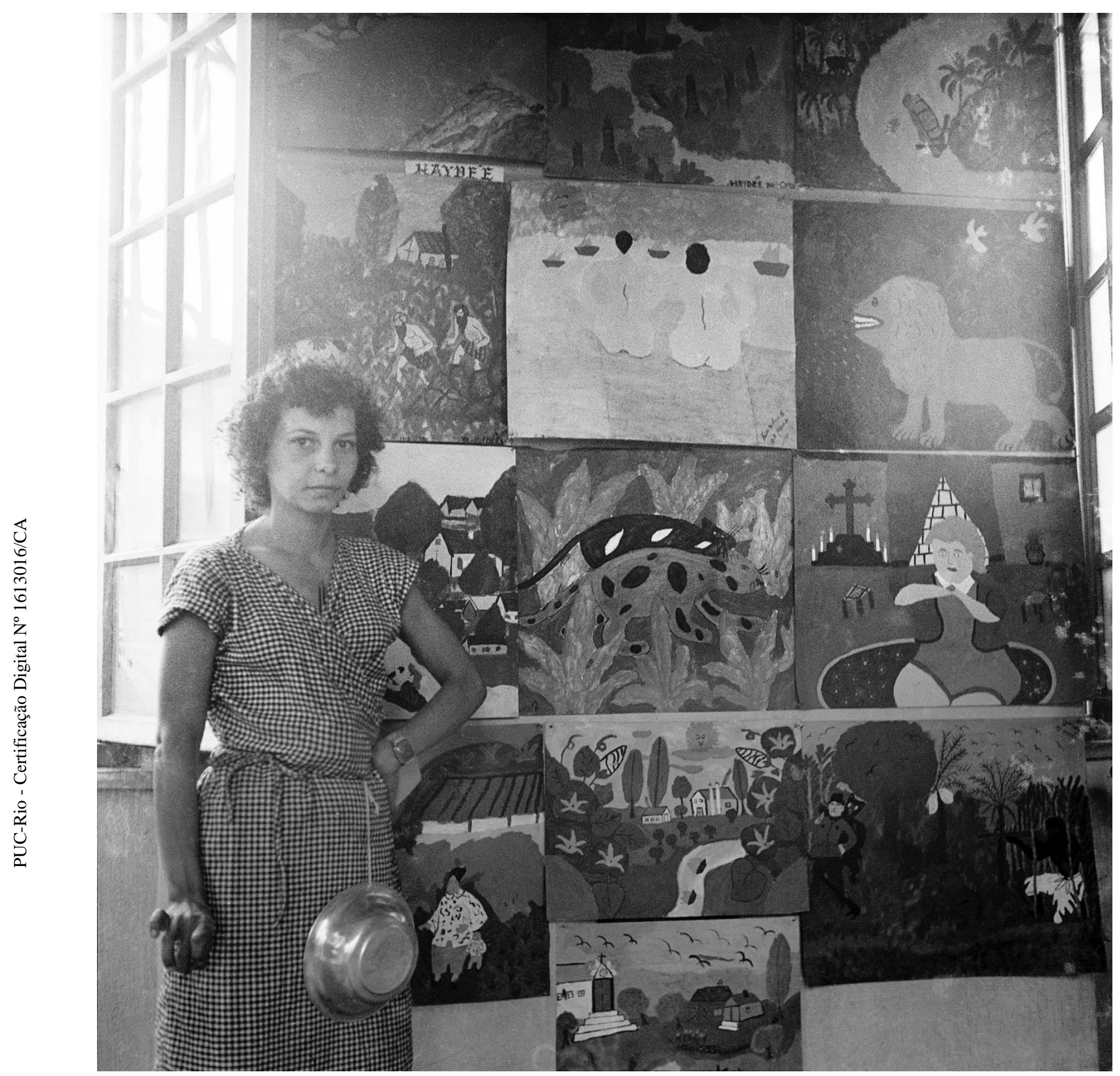

Brill, Alice. Fotografia sem título, 1950 ( Instituto Moreira Salles). 


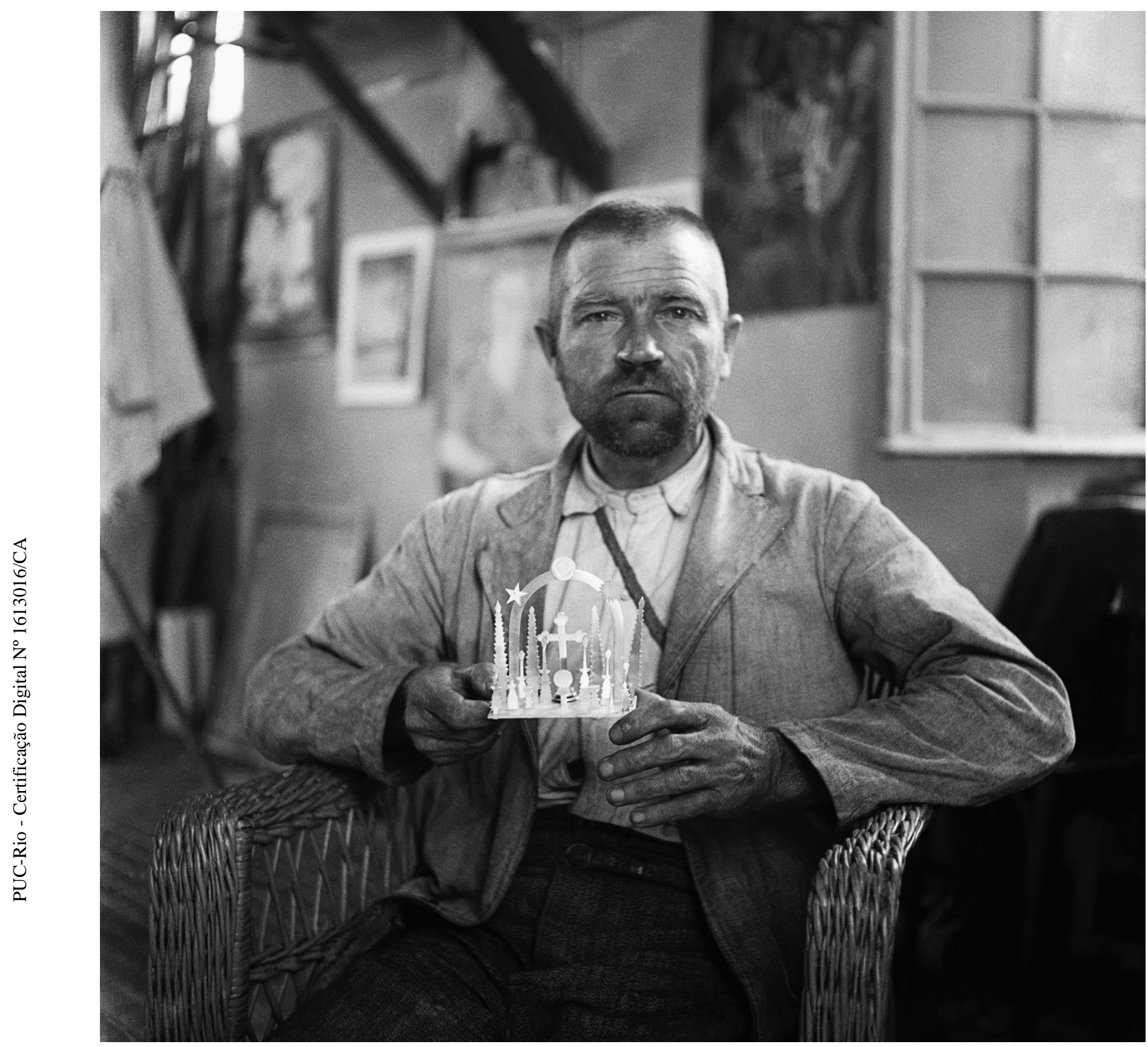

Brill, Alice. Fotografia sem título, 1950 ( Instituto Moreira Salles). 


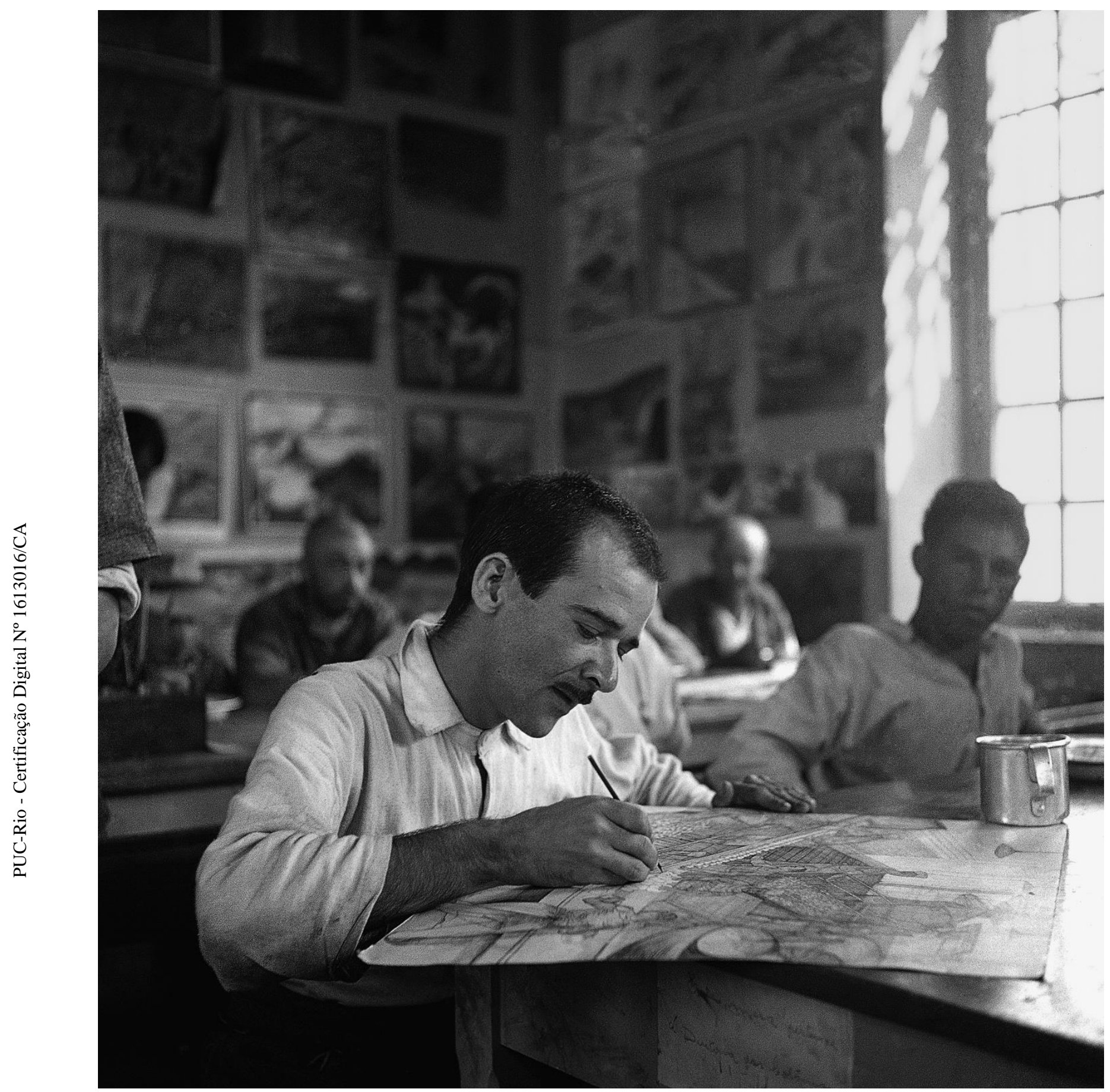

Brill, Alice. Fotografia sem título, 1950 ( Instituto Moreira Salles). 


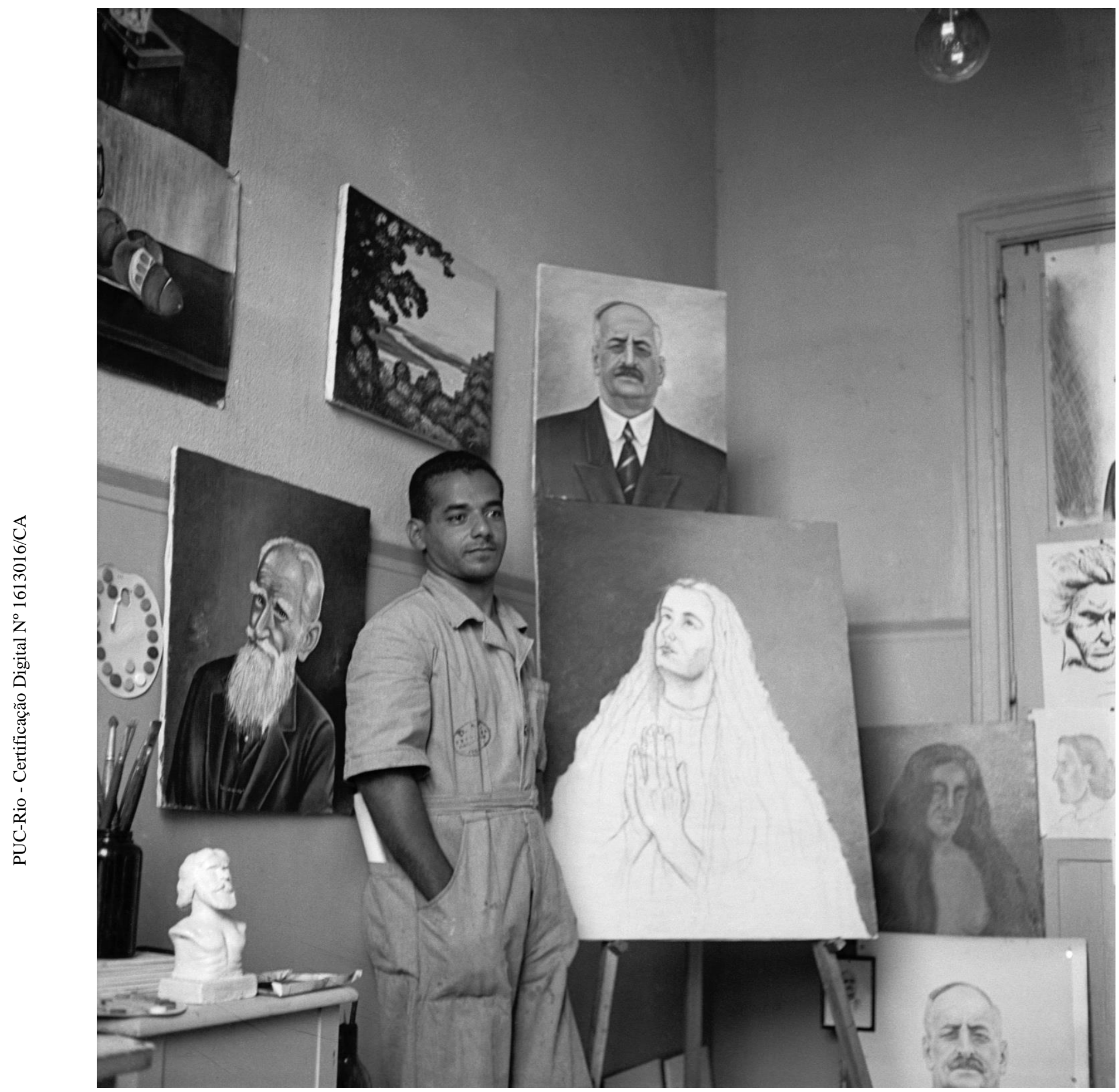

Brill, Alice. Fotografia sem título, 1950 ( Instituto Moreira Salles). 


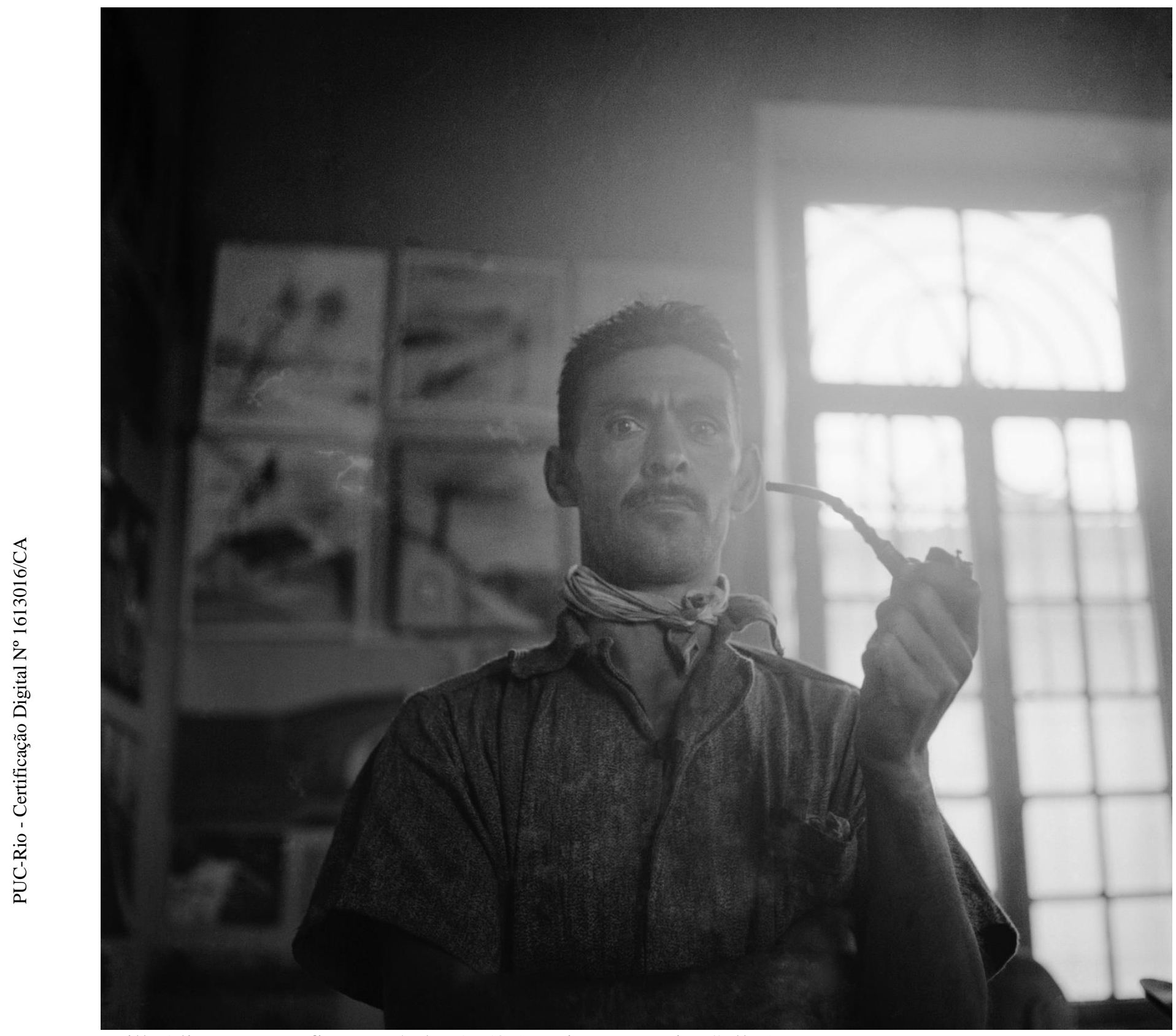

Brill, Alice. Fotografia sem título, 1950 ( Instituto Moreira Salles). 


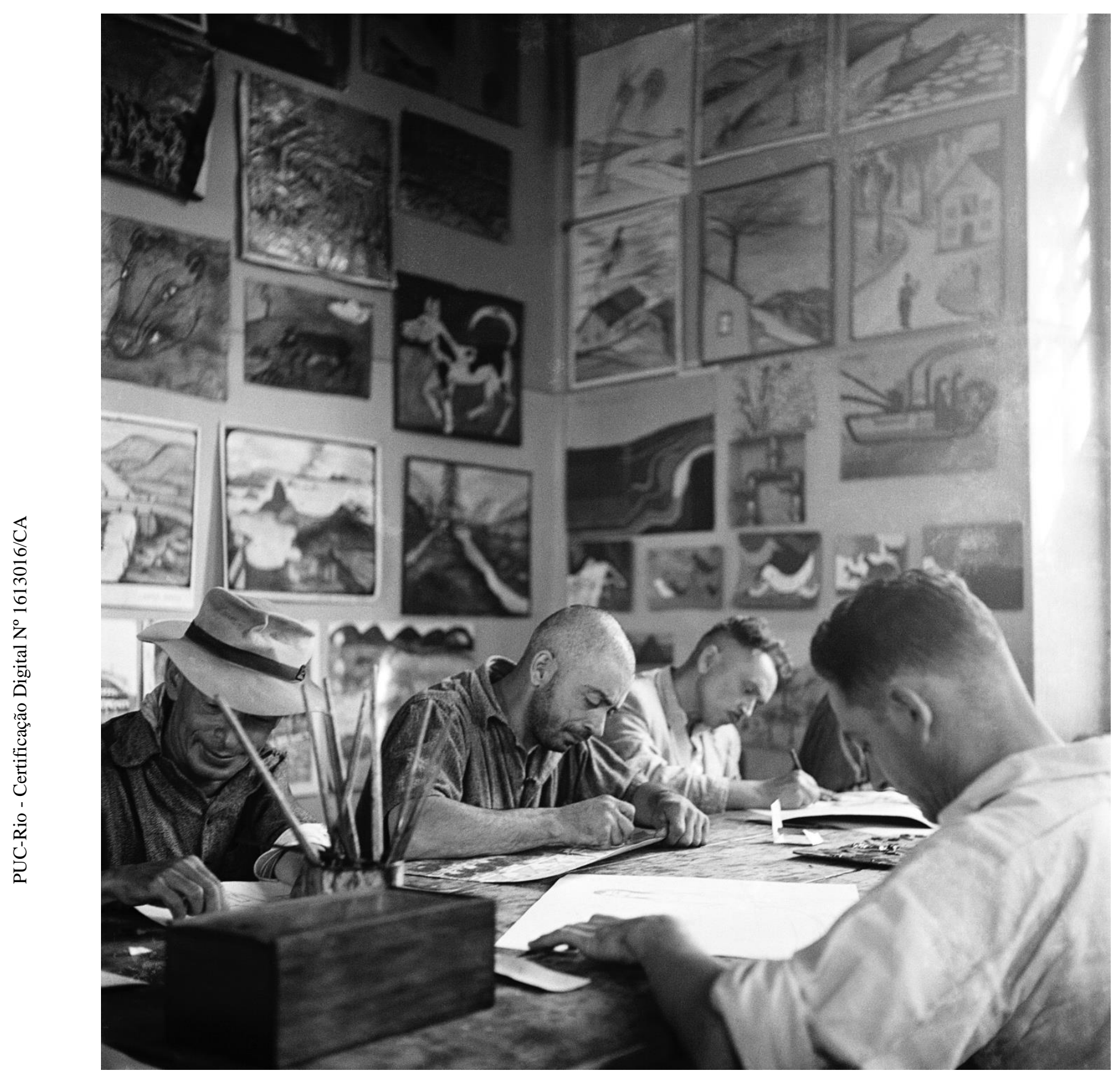

Brill, Alice. Fotografia sem título, 1950 ( Instituto Moreira Salles). 


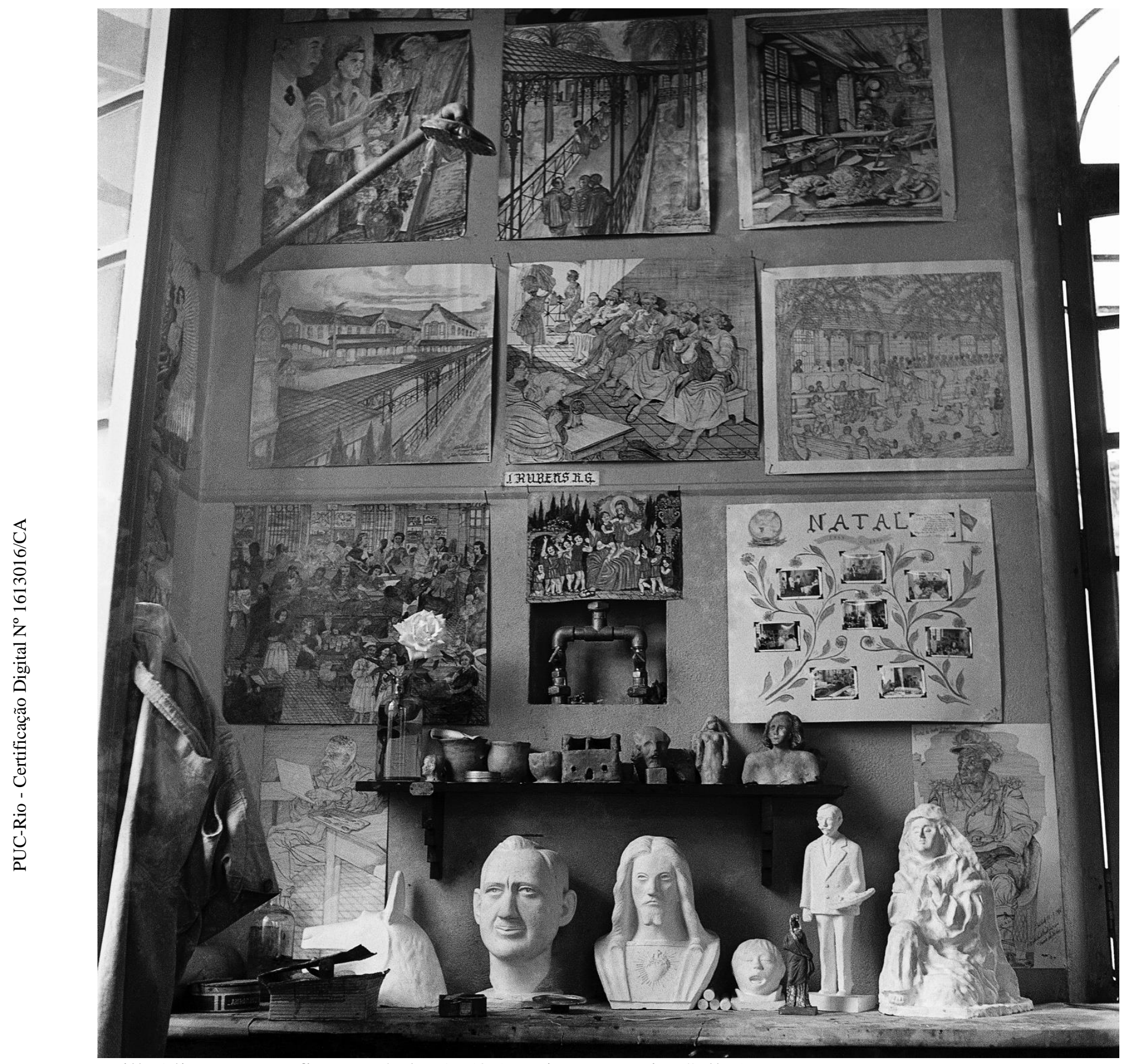

Brill, Alice. Fotografia sem título, 1950 ( Instituto Moreira Salles). 


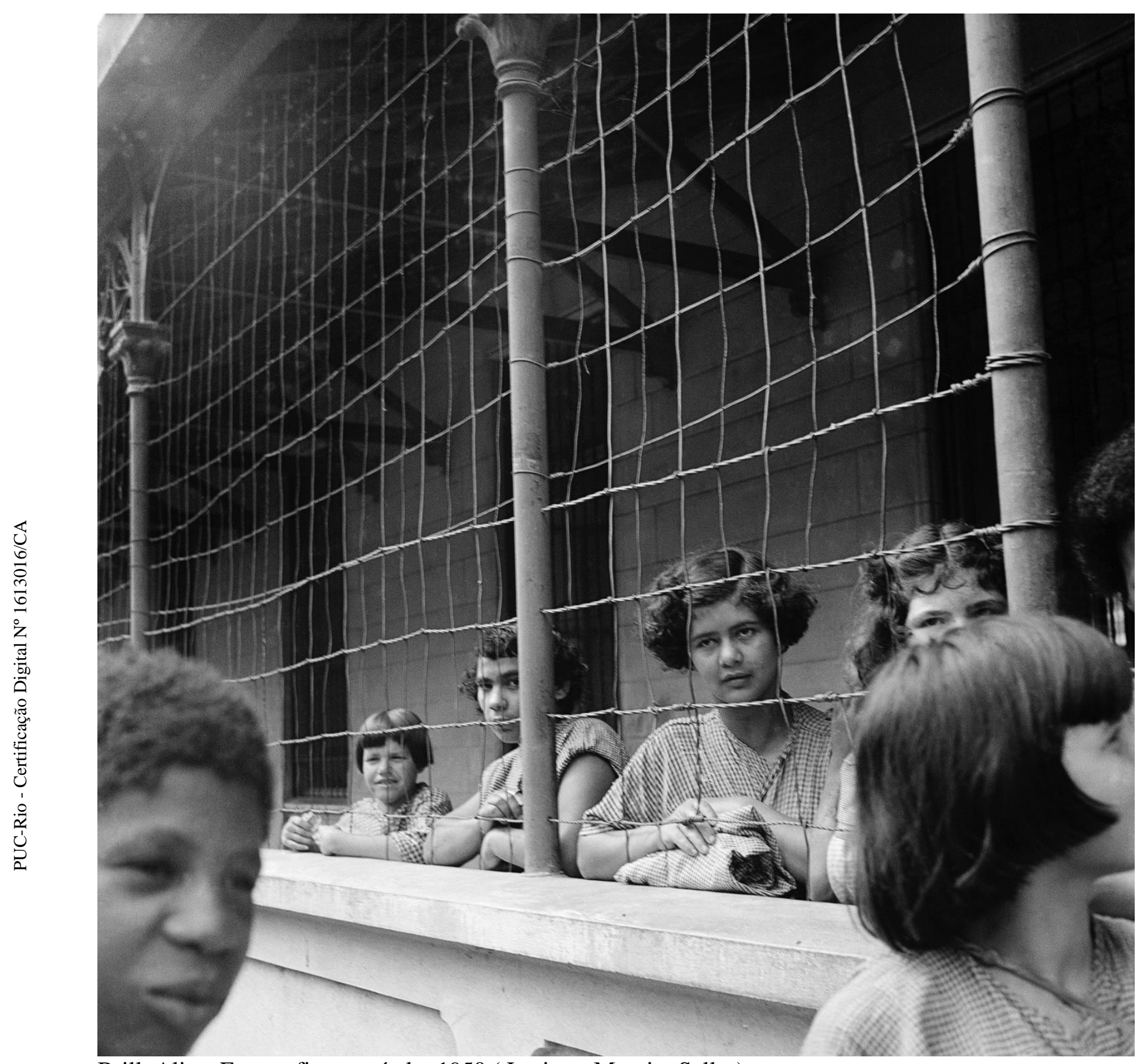

Brill, Alice. Fotografia sem título, 1950 ( Instituto Moreira Salles). 


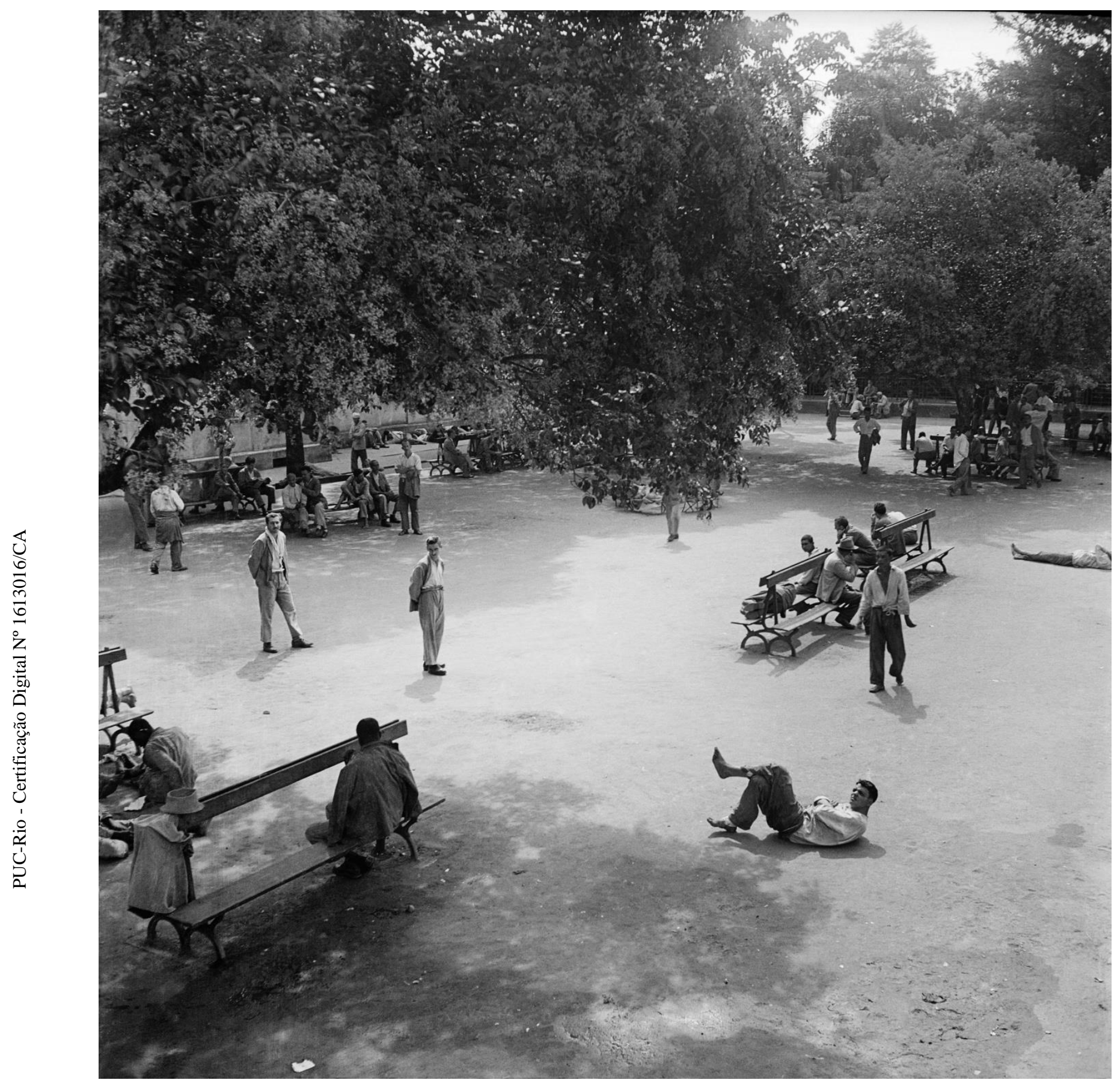

Brill, Alice. Fotografia sem título, 1950 ( Instituto Moreira Salles). 


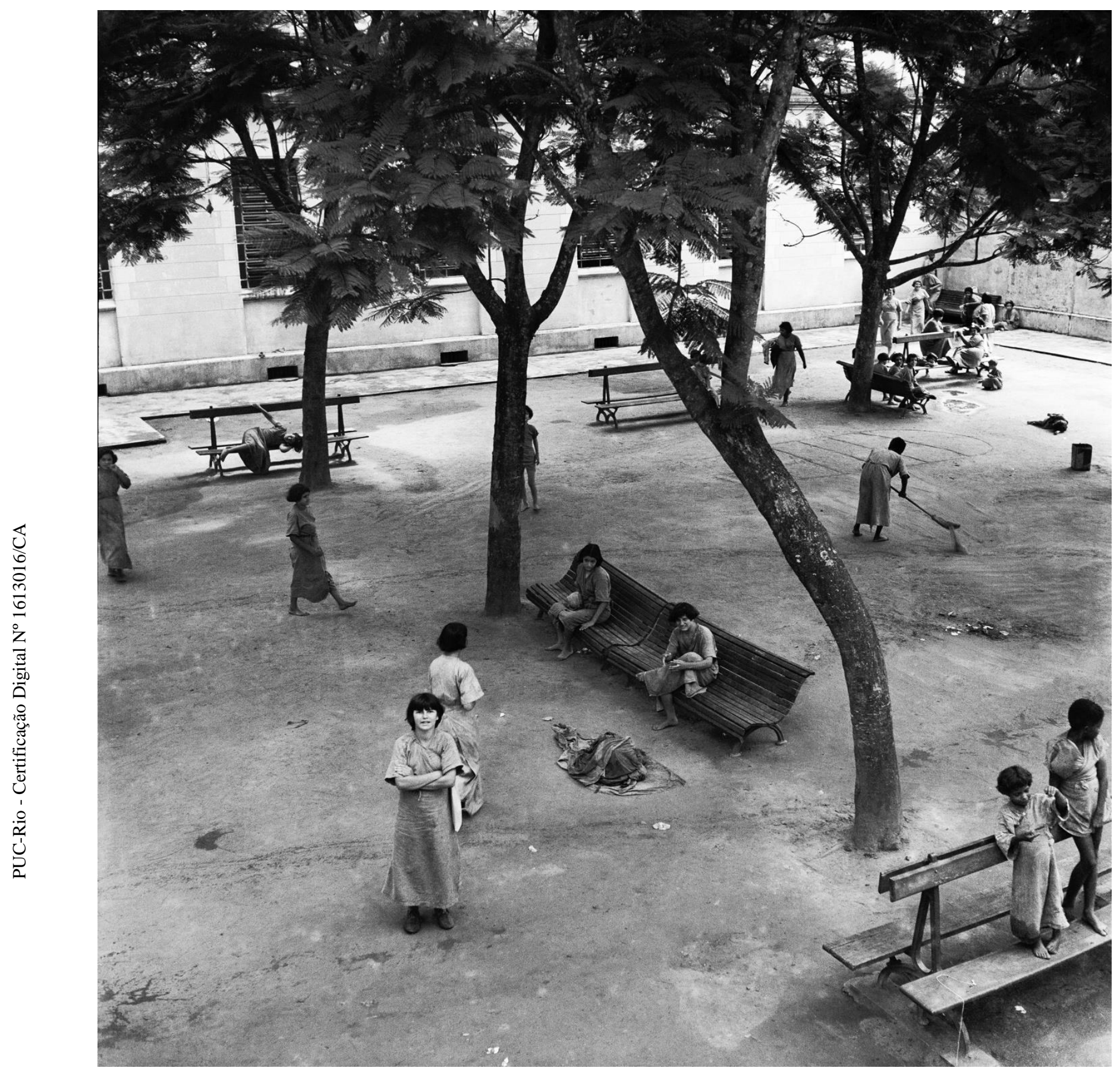

Brill, Alice. Fotografia sem título, 1950 ( Instituto Moreira Salles). 


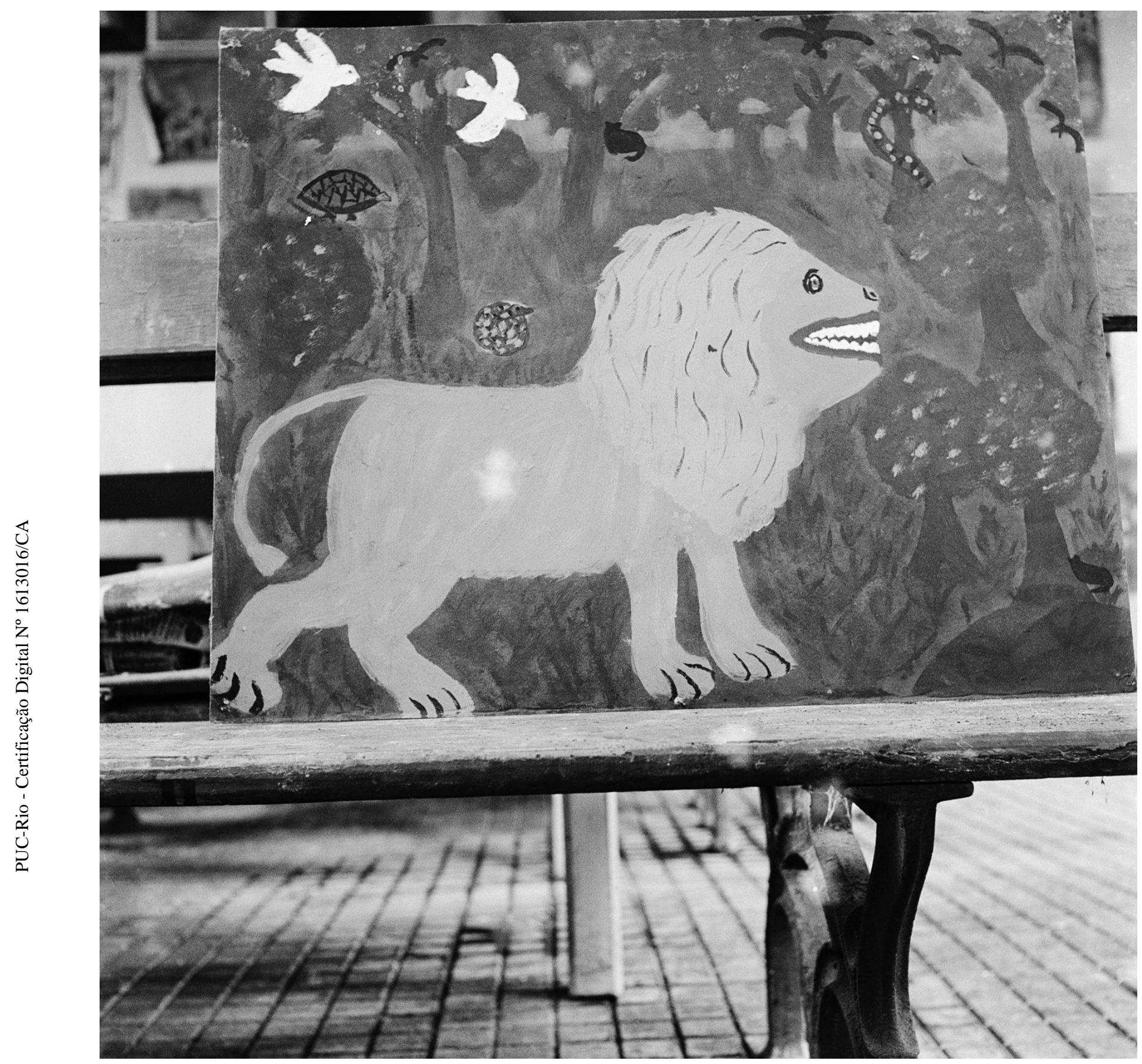

Brill, Alice. Fotografia sem título, 1950 ( Instituto Moreira Salles). 


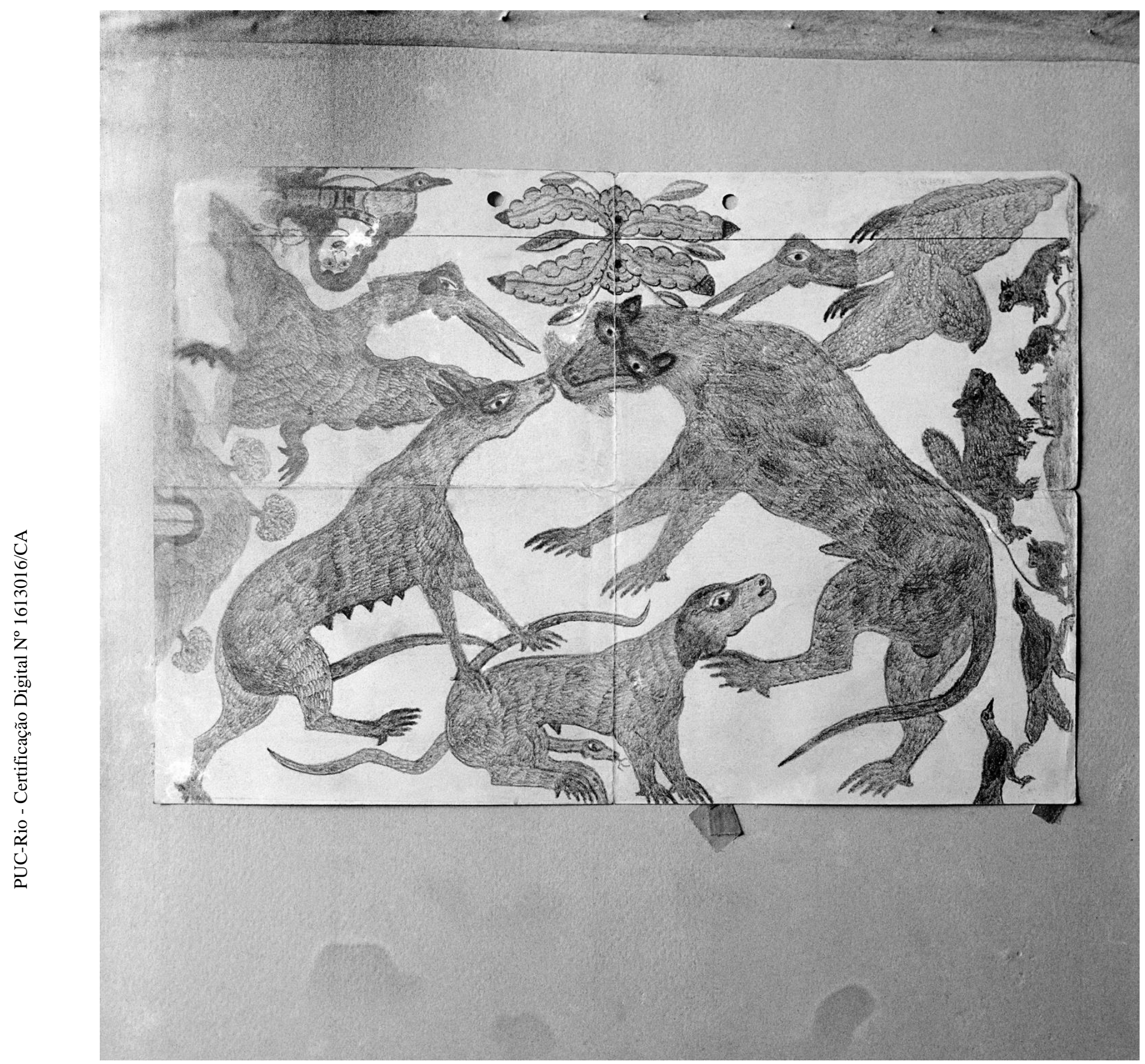

Brill, Alice. Fotografia sem título, 1950 ( Instituto Moreira Salles). 


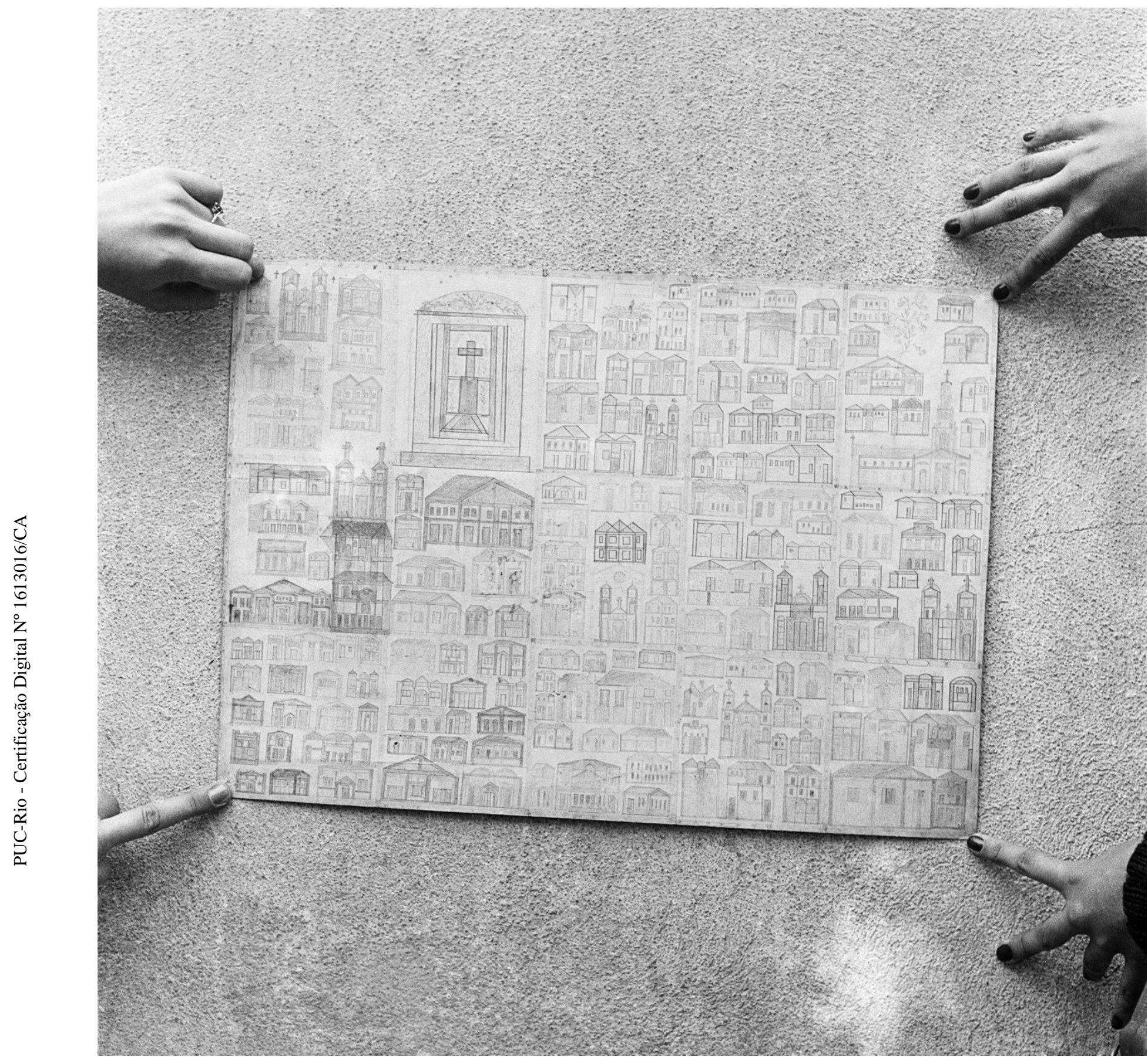

Brill, Alice. Fotografia sem título, 1950 ( Instituto Moreira Salles). 


\section{5}

\section{Considerações finais}

Esse trabalho é um primeiro esforço para os estudos ligados às novas identidades geradas a partir do fluxo de imigração causados pelas políticas do século XX. É importante ressaltar como esse processo gerou o nascimento de vanguardas artísticas e possibilitou um intenso trânsito cultural que culminou em discussões sobre os conceitos de: pátria, nação e identidade.

O intuito deste trabalho foi analisar apenas a obra fotográfica de Alice Brill que ela iniciou em 1950 e finalizou em 1960 quando saiu da revista Habitat. Ao longo dessa década, Alice Brill constrói um extenso e singular trabalho fotográfico que abrange muitos aspectos sociais e culturais do Brasil expressados de uma forma única e que proporciona diversas análises.

A partir das fotografias de Alice Brill, é possível analisar como seu olhar é singular, pela escolha de retratar sempre de forma impensável as suas séries. Neste trabalho as fotografias sobre o ateliê de arte foram escolhidas por serem um conjunto que demonstra a forma como a artista escolhe fotografar e por se tratar de um ambiente que por si só já traz um estranheza, nesse caso, pensando no hospital como um lugar que também pode ser compreendido um certo exílio. Portanto, a união do ateliê com a obra de Alice Brill se faz exatamente na arte, que foi para ela uma pátria. Essa afirmação advém não só de sua trajetória como pintora e fotógrafa, mas também em função das profissões de seus pais, ambos artistas, sua mãe escritora e seu pai artista plástico. Nesse momento há uma junção da vida desses internos com a vida de Alice Brill, seu reconhecimento de faz através da arte.

Portanto, nesse trabalho relaciono o impacto da experiência de deslocamento como motor da construção de uma obra artística singular por compreender que esses deslocamentos transformam a subjetividade, já que alargam a compreensão sobre as diferentes culturas e modos de vida.

A arte, para Alice Brill, foi uma forma de demonstrar suas percepções sobre as novas experiências pois elas são o resultado da adaptação a novas culturas, possibilitando uma experiência única, híbrida. É possível entender que o 
deslocamento possibilita uma ampliação da percepção de mundo, já que ocorria um desprendimento de suas origens.

Este trabalho apresenta uma pequena parte da vida dessa artista tão importante para a história da arte brasileira. Por se tratar de uma obra gigantesca, há para o futuro muito o que pesquisar. Estudos sobre os textos escritos por Alice Brill, uma análise da sua obra completa que começa no Grupo Santa Helena e termina na busca de novas técnicas de arte como, por exemplo, o batik são passíveis de pesquisas e reflexões. A comparação entre o trabalho escrito por sua mãe Marte Brill e seus escritos, assim como, pesquisas detalhas das poucas obras que restaram de seu pai Éric Brill são desdobramentos que serão presentes em trabalhos futuros. 


\section{6}

\section{Referências bibliográficas}

\section{Acervos pesquisados}

Arquivo Público do Estado de São Paulo - DEOPS-SP

Instituto Moreira Salles - IMS

Museu de Arte Contemporânea da Universidade de São Paulo - MAC-USP

Museu de Arte Moderna do Rio de Janeiro - MAM-RJ

University of New Mexico

\section{Referências Bibliográficas}

ALARCON, Daniela. Diário íntimo - A fotografia de Alice Brill. São Paulo, 2008. ARENDT, Hannah. A condição humana. Rio de Janeiro: Forense Universitária, 1983.

A vida do espírito. Rio de Janeiro: Civilização brasileira, 2009. Entre o passado e o futuro. São Paulo: Editora Perspectiva, 2016. Origens do Totalitarismo. São Paulo: Cia das Letras, 2012.

BHABHA, Homi K. O local da cultura. Belo Horizonte: Editora UFMG, 1998.

BARDI, Lina Bo. Lina Bo Bardi. São Paulo Impressa oficial e Instituto Lina Bo Bardi, 2008.

BRILL, Alice. Da arte e da linguagem. São Paulo: Perspectiva, 1988. (>textos para o Suplemento de Cultura do jornal O Estado de São Paulo) . Mário Zanini e seu tempo: do Grupo Santa Helena às Bienais. São Paulo: Perspectiva, 1984.

.Samson Flexor - Do Figurativismo ao Abstracionismo. São Paulo: EDUSP, 1990.

CZAPSKI, Alice Brill. "Memories from 1933-45". In: Morris, Katherine (ed.). Odyssey of exile: Jewish women flee the Nazis for Brazil. Detroit, Wayne State 
University Press,1996, pp. 146-162.

COSTA, Helouise; SILVA, Renato Rodrigues da. A fotografia Moderna no Brasil. São Paulo: Cosac Naify, 2004.

DUBOIS, Philippe. O Ato fotográfico. São Paulo: Papirus, 2012.

FLUSSER, Vilém. Bodenlos, uma autobiografia filosófica. São Paulo: Annablume, 2007. Rituras, 2008.

Da religiosidade. A literatura e o senso de realidade. São Paulo: Esc . A dúvida. Rio de Janeiro: Relume Dumará, 2009.

A escrita. Há futuro para a escrita? São Paulo: Annablume, 2010.

. Filosofia da caixa preta: ensaios para uma futura filosofia da fotografia.

São Paulo: Annablume, 2011.

Gestos. São Paulo: Annablume, 2014.

. Língua e realidade. $3^{\mathrm{a}}$ edição. São Paulo: Annablume, 2007.

. Máscaras. In: Folha de S. Paulo. 16 fev. 1972.

O mundo codificado. Por uma filosofia do design e da comunicação. São

Paulo: Cosac Naify, 2007.

GUMBRECHT, Hans Ulrich. After 1945: latency as origin of the present. Stanford: Stanford University Press, 2013.

. Depois de aprender com a História. In: Em 1926: vivendo no limite do tempo. Rio de Janeiro: Record, 1997.

. Modernização dos sentidos. São Paulo: Ed. 34, 1998.

. Produção de presença. Rio de Janeiro: Contraponto/Editora PUC-Rio, 2004.

GONÇALVES, Tatiana Fecchio da Cunha. A representação do louco e da loucura nas imagens de quatro fotógrafos brasileiros do século XX: Alice Brill, Leonid Streliaev, Cláudio Edinger, Claudia Martins. Tese (doutorado) Instituto de Artes, Universidade Estadual de Campinas, São Paulo, 2010.

FERRAZ, Maria Heloísa C. de Toledo, Juquery, encontros com a Arte. In: Juquery cem anos, São Paulo, 1998.

FERRAZ, Maria Heloísa C. de Toledo. O pioneirismo de Osório César. In: Arte e inconsciente: três visões sobre o Juquery. Instituto Moreira Salles: São Paulo, 2002. 
JENSEN, Silvina. "Exílio e Historia Reciente: Avances y perspectivas de un campo en construción”. In: Aletheia, v. 1, n. 2, mayo 2011.

JUDT, Tony. Pós Guerra - Uma História da Europa desde 1945. Rio de Janeiro: Editora Objetiva, 2003.

KOSELLECK, Reinhart. Critica e crise. Rio de Janeiro: Eduerj - Contraponto, 1999.

Futuro passado. Rio de Janeiro: Contraponto/Editora PUC-Rio, 2011.

KOSSOY, Boris. Fotografia e história. São Paulo: Ateliê Editorial, 2001.

KOSSOY, Boris. Origens e expansão da fotografia no Brasil. Rio de Janeiro Ed

Funarte, 1980.

KOSSOY, Boris. Os Tempos da fotografia: o efênero e o perpétuo. Cotia, São Paulo:Ateliê Editorial, 2007.

KOSSOY, Boris. Realidades e ficções na trama fotográfica. São Paulo: Ateliê Editorial, 2002.

KRAUSS, Rosalind. O fotográfico. Tradução: Anne Marie Davée. Barcelona: Editions Macula,1990.

HOBSBAWM, Eric J. Era dos extremos: o breve século XX: 1914-1991. São Paulo: Companhia das Letras, 1995.

MAUAD, Ana Maria. "O olhar engajado: fotografia contemporânea e as dimensões políticas da cultura visual”. In: ArtCultura, Uberlândia, v. 10, n. 16, jan.-jun. 2008. pp. 33-50. Disponível em: <http://www.artcultura.inhis.ufu.br/PDF16/A_Mauad.pdf> Acesso em 24 jun. 2018.

MAUAD, Ana Maria. Sob o signo da imagem: a produção da fotografia e o controle dos códigos de representação social da classe dominante no Rio de Janeiro, na primeira metade do século XX. 1990. 637 f. Tese (Doutorado em História) - Instituto de Ciências Humanas, Universidade Federal Fluminense. Rio de Janeiro,1990.

OGAWA, Carla Cristina. Vista do Atelier: dualidades simultâneas e a conquista do horizonte. Um olhar sobre a produção pictórica de Alice Brill. Dissertação de mestrado apresentada à Faculdade Santa Marcelina, São Paulo, 2008. 
PARADA, Maurício Barreto Alvarez. “A fundação do Museu de Arte Moderna do Rio de Janeiro: A elite carioca e as imagens da modernidade no Brasil dos anos 50". In: Revista Brasileira de História, São Paulo, v. 27, 1995.

RIBEIRO, Adelia Maria M. "Intelectuais no exílio: onde é a minha casa?". In: Dimensões, vol. 26, 2011. pp. 152-176.

RIBEIRO, Adelia Maria M. "Intelectuais, diáspora e cultura: por uma crítica anti moderna e pós colonial”. In: Mouseion, n. 12, 2012. pp. 41- 55. Disponível em:

<http://www.revistas.unilasalle.edu.br/index.php/Mouseion/article/viewFile/4 02/408> Acesso em 26 jun. 2017.

RICOEUR, Paul. Autobiografia intelectual. Buenos Aires: Ediciones Nueva Vision, 2007.

SAID, Edward. Representações do intelectual: as Conferências Reith de 1993. São Paulo: Companhia das Letras, 2005.

SAID, Edward. Fora do Lugar. São Paulo: Companhia das Letras, 2004.

SAID, Edward. Reflexões sobre o exílio. São Paulo: Companhia das Letras, 2003.

SONTAG, Susan. Sobre Fotografia. São Paulo: Companhia das letras, 2004.

SONTAG, Susan. Introdução. In: Contra a interpretação. Porto Alegre: L\&PM, 1987.

SONTAG, Susan. Diante da dor dos outros. São Paulo: Companhia das Letras, 2003.

STUART, Hall. A identidade cultural na pós modernidade. Rio de Janeiro: DP\&A Editora, 2005.

TRAVERSO, Enzo. La Historia como campo de Batalla - interpreter las violências del siglo XX. Buenos Aires: Fondo de Cultura económica, 2012.

VIERA, José Geraldo: A arte ingênua. In: Habitat. Arquitetura e Artes no Brasil, Vol. 35. 1956

YAHN, Mario: Pintores sem saber. In: Habitat. Arquitetura e Artes no Brasil, Vol.2,1951. 
YAHN, Mario. Sobre a criação de uma secção de arte no Hospital de Juquerí.

Boletim de Higiene Mental. São Paulo, Instituição de Assistência Social ao Psicopata, ano VI, n.66, fev. 1950. 